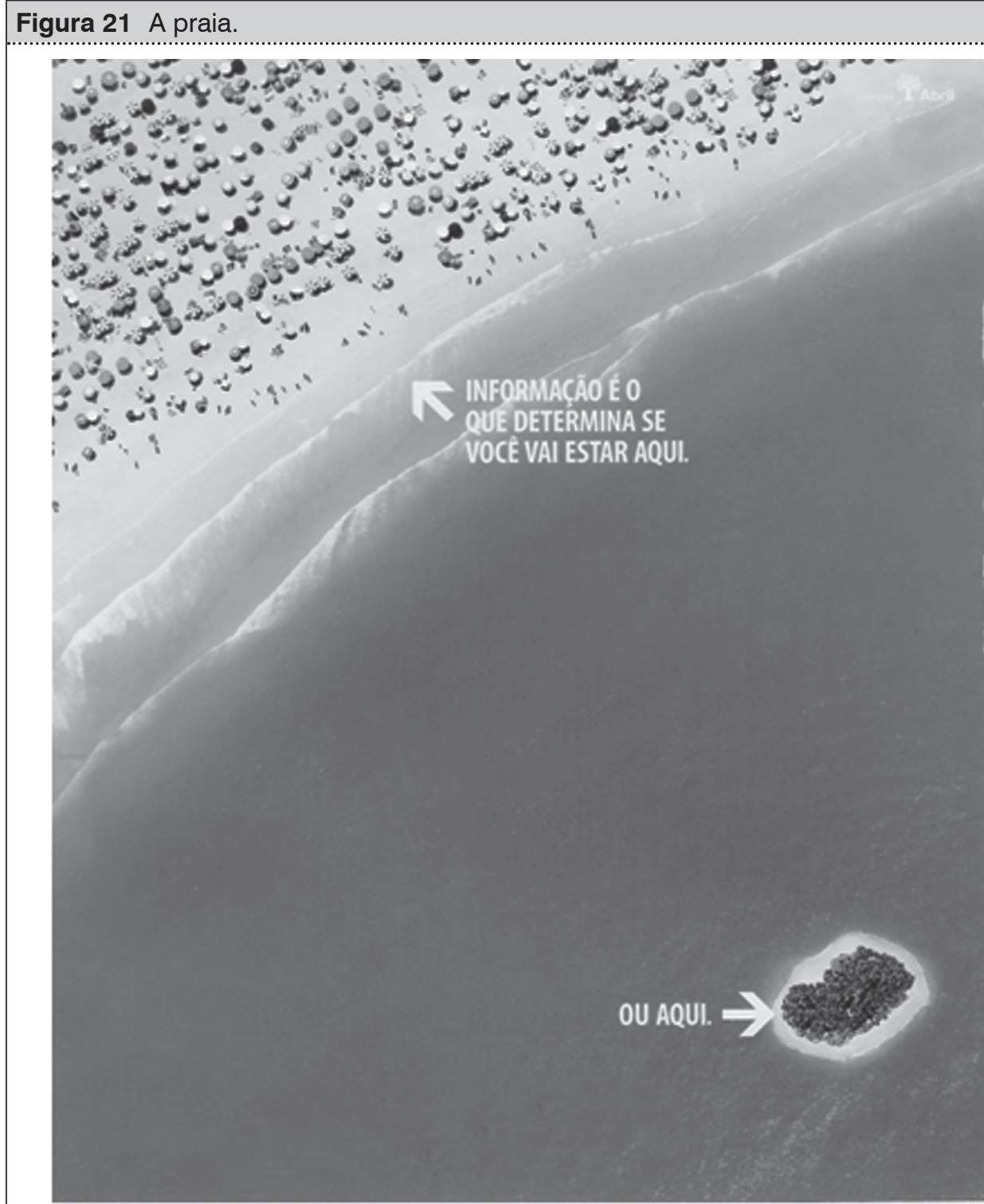

Fonte: UPDATE. Revista mensal da Câmara America de Comércio de São Paulo, Abril/2005, ano xxi, n. 414. 



\title{
Análise dos dados e discussão dos resultados - Parte I
}

\author{
Compreender as manifestações práticas da prática avaliativa \\ é ao mesmo tempo compreender aquilo que nela está oculto.
}

Vera Lúcia Camara F. Zacharias ${ }^{1}$

Efeito retroativo positivo deve ser a meta principal de um elaborador de exame. ${ }^{i}$

Bailey $^{2}$

No capítulo anterior, apresentei a base metodológica para esta investigação. Neste capítulo, estruturado em três seções principais, analisarei e discutirei os dados. Na seção 4.1, farei a análise de documentos: na sub-seção 4.2.1, os documentos LDB, PCNEM, PCN+, DNEM serão estudados; na 4.2.1, as provas de inglês do vestibular da UFPR serão analisadas; na 4.2.3 os documentos das escolas elaborados pelos professores e orientadores/coordenadores serão vistos, e, na 4.2.4 é a vez do manual do candidato ser contemplado. Na sub-seção Verificarei suas contribuições para a configuração do ensino da língua no ensino médio, observando se há convergência com a filosofia do exame vestibular. Na seção 4.2, abordarei as impressões dos elaboradores do exame sobre a prova de língua inglesa do vestibular da UFPR. Na última seção, 4.3, procurarei depreender a opinião da coordenadora para o ensino de língua inglesa da Secretaria Estadual da Educação sobre o ensino da língua inglesa nas escolas estaduais e sobre o vestibular da UFPR.

1 ZACHARIAS, Vera Lúcia Camara F. Avaliação para quê? Disponível em: <http://www.centrorefeducacional.com.br/avapque.htm>. Acesso em: 17 abr. 2006.

2 BAILEY, K. Working for washback: a review of the washback concept in language testing. In: Language Testing. 13(3), 1996. p. 261 


\subsection{OS DOCUMENTOS}

Os documentos que foram analisados neste estudo foram: Lei de Diretrizes e Bases n. 9.394; Diretrizes Curriculares Nacionais para o Ensino Médio DCNEM; Parâmetros Curriculares Nacionais do Ensino Médio - PCNEM; PCN+, Parecer do Conselho Nacional de Educação sobre a Reforma do Ensino Médio n.15/98; Parâmetros Curriculares Nacionais do Ensino Médio em Debate; PCNEM e PCN+ de Línguas Estrangeiras (LE) no Ensino Médio - Orientações Curriculares do Ensino Médio; os exame de inglês do vestibular da UFPR de 1972 até 2006 e os planejamentos/ementas das escolas públicas.

\subsubsection{Documentos oficiais}

Os PCN+ foram escritos para complementar os $\mathrm{PCNEM}^{3}$ em uma tentativa de corrigir a superficialidade deste último. É um documento muito mais extenso, com 45 páginas. Ambos carecem de fundamentação teórica clara, como bem diz Rojo e Moita Lopes (2004, p. 42).

Os PCNEM são um documento de poucas páginas (12), e que não chega a referenciar as mudanças propostas pela LDBEN e Diretrizes. As seis primeiras páginas se ocupam em descrever o ensino de LE no passado e os objetivos de se ensinar LE no ensino médio: conhecimento necessário para ingressar no mundo do trabalho e para o desenvolvimento da cidadania. O documento postula um ensino da LE com o foco nas 4-Hs, ou seja, quatro habilidades - falar, compreender, ler e escrever, além de reforçar a necessidade dos profissionais referenciarem seu ensino no caráter formativo, isto é, preparar os alunos para práticas sociais nas quais eles possam desenvolver sua cidadania plena.

Ao postular um ensino embasado em um conceito de competência comunicativa que envolve as competências gramatical, sociolingüística, discursiva e estratégica (p. 58), nota-se que o texto postula desenvolver competências. Tal documento sugere o modelo de Canale e Swain na medida em que se refere as competências supracitadas, sem, entretanto, dar o crédito aos dois autores, pois somente Canale é citado na bibliografia. Outro problema, de caráter teórico, aparece quando o autor afirma que outras competências (além da gramatical, sociolingüística, discursiva e estratégica) têm que ser integradas ao ensino, tais como: "saber distinguir entre as variantes lingüísticas"; "escolher o registro adequado à situação na qual se processa a comunicação"; "compreender de que forma determinada expressão pode ser interpretada em razão de aspectos

http://portal.mec.gov.br/seb/arquivos/pdf/linguagens.pdf 
sociais e/ou culturais"; "compreender em que medida os enunciados refletem a forma de ser, pensar, agir e sentir de quem os produz"; "escolher os vocabulários que melhor reflitam a ideia que se pretende comunicar"; "utilizar os mecanismos de coerência e coesão na produção em Língua Estrangeira (oral e/ou escrita)"; "utilizar as estratégias verbais e não verbais para compensar falhas na comunicação". Ora, as quatro primeiras competências supracitadas fazem parte da competência sociolingüística, a quinta e sexta da discursiva e a última da estratégica, ou seja, tais competências, dentre muitas outras, fazem parte da competência comunicativa descrita por Canale e Swain e Canale e não são "demais competências" (p. 56) a serem trabalhadas como se não fizessem parte do modelo como um todo. Além disso, há muitos outros atributos a serem trabalhados dentro do modelo, além dos sete citados (p. 57). A teoria de Canale e Swain (1980) e Canale (1983) foi reduzida e muito superficialmente descrita, o que, inevitavelmente, dificultará qualquer tentativa de compreensão do modelo, e, pior ainda, inviabilizará a construção de uma proposta pedagógica bem fundamentada.

Também os PCN+ continuam sugerindo o modelo de Canale e Swain (1980) e Canale (1983), sem lhes dar os devidos créditos (p. 101, 102 e 121) nem no texto, e, dessa vez, nem na bibliografia. Além disso, há uma listagem de sete competências a serem trabalhadas (p. 107-8), todas apresentadas como se não fizessem parte da competência comunicativa descrita por Canale e Swain (1980) e Canale (1983), mas que, na verdade, fazem parte ou da competência sociolingüística ou da estratégica ou da discursiva ou da gramatical. No documento, não há uma definição dos conceitos de competência e habilidades e nem quais competências e habilidades devem ser trabalhadas. Seria bom lembrar que o ensino por competências encontra-se atualmente em outro estágio de avanço teórico, ou seja, novos modelos de competência comunicativa não foram contemplados (Bachman, 1990; Bachman e Palmer, 1996).

Mas o maior problema do documento é a fragmentação teórica e a inclusão de várias concepções de linguagem - muitas vezes antagônicas -, que aparecem no texto. Numa tentativa de enquadrar as concepções comunicativistas no arcabouço geral dos PCN - representação e comunicação, investigação e compreensão, e contextualização sócio-cultural (um dos objetivos descritos no documento a ser alcançado) - o autor subdividiu essas três grandes áreas em conceitos, competências e habilidades. Dentro de cada subdivisão, há definições

4 Na página 122, o autor prega que é necessário "fazer uso adequado de citações e créditos, sempre que pertinente!" 
de atributos que devem compor o ensino de LE (linguagem verbal, não verbal, e digital; signo e símbolo, denotação e conotação etc.). Como afirma Rojo e Moita Lopes (2004, p. 43), "não é possível entender nem as definições sobre os subitens, nem como se relacionam entre si do ponto de vista teórico".

Outro problema é a inconsistência na proposta de objetivos para o ensino de LE. Para o autor, "o foco de aprendizado deve centrar-se na função comunicativa por excelência, visando prioritariamente a leitura e a compreensão de textos verbais orais e escritos" (p. 94). Embora o autor afirme que a leitura deve ser a habilidade a ser priorizada, nota-se, ao longo do texto, uma proposta para o ensino da oralidade ora centrada em funções comunicativas (p. 94), ora em temas (p. 106).

Além da incoerência de objetivos propostos para o ensino de LE, outros equívocos são cometidos quando o autor propõe o ensino de leitura. A visão de leitura do documento ainda é aquela pautada nas teorias tradicionais ascendentes de leitura. Primeiro, ele usa em todo texto as palavras "ler e interpretar" como se fossem duas coisas distintas. Na visão de leitura como construção de sentidos, ler pressupõe compreender e interpretar. Se um leitor lê e não interpreta, não compreende, e portanto, não sabe ler. Numa visão tradicional ascendente, no entanto, ler é decodificar e interpretar é entender, como se fossem duas atividades distintas. Essa visão pode ser percebida quando ele afirma:

O professor e o grupo auxiliarão na decodificação do vocabulário novo que for essencial para compreensão e interpretação. É fundamental que o aluno capte o significado como um todo, sem necessariamente traduzir todas as palavras (p. 113).

Decodificar um texto implica construir hipóteses, proceder a explorações da estrutura gramatical arriscar-se na descoberta do significado de novos vocabulários (p. 114).

Outra importante classe de palavras-ferramenta, os substantivos constituem apoio fundamental na decodificação do texto, por sua associação com adjetivos e outros determinantes textuais (p. 119).

A competência primordial do ensino de línguas estrangeiras modernas no ensino médio deve ser a da leitura e, por decorrência, a da interpretação. (p. 97)

Outras "técnicas" sugerem uma visão tradicional de leitura:

Primeiramente, os alunos devem fazer a leitura individual e, depois, o professor pode ler o texto pausadamente, esclarecendo ao final as palavras que apresentarem maior grau de dificuldades. (p. 113) 
O uso de textos como ponto de partida do processo de ensino e aprendizagem de um idioma estrangeiro envolve, em primeira instância, a língua falada: leitura em voz alta, exploração do vocabulário desconhecido, questões simples que possam auxiliar a desvendar o sentido geral contido no texto, formuladas em línguas estrangeiras pelo professor para a classe. (p. 115) Desenvolvimento de técnicas de tradução e versão, partindo de palavras-chave e de palavras-ferramenta (verbos, substantivos, conjunções). (p. 105)

Como podemos notar, o professor é sempre centralizador no processo de leitura. Ele lê e "esclarece" as palavras mais difíceis. O texto vira um pretexto para oralidade e o professor é o detentor do poder de "elaborar questões simples para a classe", o que constitui uma visão tradicional de ensino de LE. Uma visão ascendente de leitura sugerida através de técnicas como as acima, aparece lado a lado com as técnicas empregadas no ensino intrumental: ${ }^{5}$ skimming, scanning, predicting etc. É interessante observar que o documento traz duas visões antagônicas de leitura: a tradicional, que está pautada em estratégias ascendentes de leitura (decodificação dolorosa das letras em fonemas; de fonemas em palavras; das palavras em orações; das orações em parágrafos; dos parágrafos em texto), e a instrumental, que é pautada em estratégias descendentes (criar hipóteses do texto a partir de seu conhecimento de mundo etc.). A inconsistência do documento sobre concepções de leitura também pode ser percebida quando o autor sugere a aplicação das técnicas de uma abordagem instrumental:

O substrato sobre o qual se apoia a aquisição dessas competências constitui-se no domínio de técnicas de leitura - tais como skimming, scanning, prediction - bem como na percepção e na identificação de índices de interpretação textual. (p. 97)

É essencial o desenvolvimento de técnicas de leitura que obrigatoriamente envolvam atividades de pré-leitura e de preparação para a compreensão propriamente dita: guessing, exploração oral prévia do assunto e do temas, levando sempre em conta o conhecimento anterior do aluno. Técnicas como skimming e scanning do texto, levantamento de palavras-

5 O Projeto Instrumental teve início na PUC-SP, no início dos anos 80, e propunha um modelo de leitura baseado em estratégias descendentes, ou seja, o leitor trazia para o texto seu conhecimento prévio do assunto e de mundo, e, a partir de elementos mínimos do texto, construía os sentidos possíveis. 
chave e pesquisa de vocabulário reforçam o aprendizado autônomo e significativo. (p. 109)

O trabalho eficaz com textos depende também do desenvolvimento de técnicas de leitura, essenciais para a vida acadêmica e profissional. As técnicas do skimming (leitura corrida para se apreender o sentido geral do texto), e de scanning (leitura mais detalhada em que se buscam informações específicas) são etapas essenciais para o processo de análise semântica e estrutural. Devem, portanto, ser intensivamente desenvolvidas em sala de aula, bem como as atividades de guessing e de pré-questions. (p. 116)

E contradiz sua sugestão na página 108, ao dizer que "não se trata de dar destaque ao ensino da língua instrumental".

O documento, por mostrar contradições nas concepções de linguagem e leitura, dificulta, senão inviabiliza, a definição de qualquer objetivo coerente e coeso para o ensino de LE, muito menos um ensino que prepare os alunos para serem leitores proficientes e, assim, estarem aptos para enfrentarem um exame de leitura em inglês no vestibular.

Os PCN+ não dão subsídios suficientes e necessários para que os professores preparem seus alunos para serem leitores proficientes, e em decorrência disso, para o exame de leitura para o vestibular, pois afirmam que o novo ensino médio não mais serviria como preparatório para o ensino superior (apesar de se contradizerem ao afirmar que "eventualmente os alunos possam prosseguir os estudos" - p. 8), mas centralizaria seus esforços para preparar os alunos para a vida, qualificá-los para a cidadania e capacitá-los para o aprendizado permanente.

O novo ensino médio, nos termos da Lei, de sua regulamentação e encaminhamento, deixa, portanto, de ser apenas preparatório para o ensino superior ou estritamente profissionalizante, para assumir a responsabilidade de completar a educação básica. Em qualquer de suas modalidades, isso significa preparar para a vida, qualificar para a cidadania e capacitar para o aprendizado permanente, seja no eventual prosseguimento dos estudos, seja no mundo do trabalho. (p. 08)

Mais uma vez, questiono: o que é preparar para vida? Para que tipo de vida? Preparar o aluno para ser bem sucedido em um vestibular não é preparálo para vida? O documento define o que é formar para vida:

Num mundo como o atual, de tão rápidas transformações e de tão difíceis contradições, estar formado para a vida significa mais do que reproduzir dados, denominar classificações ou identificar símbolos. Significa: 
- $\quad$ saber se informar, comunicar-se, argumentar, compreender e agir;

- $\quad$ enfrentar problemas de diferentes naturezas;

- $\quad$ participar socialmente, de forma prática e solidária;

- $\quad$ ser capaz de elaborar críticas ou propostas; e

- $\quad$ especialmente, adquirir uma atitude de permanente aprendizado.

Uma formação com tal ambição exige métodos de aprendizado compatíveis, ou seja, condições efetivas para que os alunos possam:

- $\quad$ comunicar-se e argumentar;

- defrontar-se com problemas, compreendê-los e enfrentá-los;

- participar de um convívio social que lhes dê oportunidades de se realizar como cidadãos;

- $\quad$ fazer escolhas e proposições;

- $\quad$ tomar gosto pelo conhecimento, aprender a aprender.

Se, de fato, a escola pautasse seu ensino com os objetivos supracitados, não estaria ela preparando o aluno tanto para o trabalho, para a cidadania, quanto para continuar os estudos em nível superior? Não seria um equívoco polarizar 'ensino para vida' versus 'ensino para o vestibular'? Não é um equívoco afirmar que 'a escola não servirá como preparatório para o ensino superior' e, ao mesmo tempo, propor um ensino, que se for efetivamente desenvolvido, inevitavelmente, o preparará tanto para o trabalho quanto para o vestibular?

Porém, hoje, o que se pode observar é que com a atual qualidade do ensino público, os alunos são preparados para serem cidadãos desempregados, por falta de qualificação profissional, ou privados de um padrão melhor de vida devido aos empregos de baixa remuneração que conseguem obter.

O documento também afirma que devemos educar para a cidadania. Mas que tipo de cidadão se pensa em formar com a atual escola pública? Cidadãos que não têm capacidade para exercer seus direitos e são tolhidos de viver uma democracia plena, por falta de conhecimentos básicos, inclusive da língua materna (Rojo e Moita Lopes, 2005), conhecimentos esses que contribuem para construção de um cidadão de fato. Ao negar aos alunos um ensino que oportuniza o acesso ao ensino superior, o documento, de antemão, não estaria os discriminando?

Pude observar que, no Estado do Paraná, o problema inicia-se no descumprimento de algumas recomendações feitas no documento:

- $\quad$ Não há um programa ou currículo coeso e coerente interligando os sete anos nos quais a língua estrangeira é ensinada. Não há uma seqüência coesa e coerente do que é ensinado da $5^{\mathrm{a}}$ série para $6^{\mathrm{a}}$, da $6^{\mathrm{a}}$ 
para $7^{\mathrm{a}}$, e assim por diante. Não há uma seqüência lógica e coerente entre o que é ensinado no ensino fundamental e médio.

- No ensino médio, a língua estrangeira não é obrigatória nos três anos. Algumas escolas incluem a língua estrangeira nos três anos, mesmo com uma carga horária bem reduzida, mas outras somente a incluem no último ano do ensino médio, impossibilitando o professor de desempenhar qualquer trabalho seqüencial, coeso e coerente.

Finalmente, os professores ao serem perguntados sobre os PCNEM, $\mathrm{PCN}+$ e documentos oficiais, foram unânimes em dizer que tinham dificuldade em entendê-los e dificuldade maior em operacionalizá-los. O nível teórico que um profissional necessita ter para poder interpretar, compreender e criticar os documentos não corresponde ao nível que a grande maioria desses profissionais têm. Os professores das escolas particulares e cursos pré-vestibulares nem sequer lêem os documentos e os da escola pública afirmaram que não os levam em consideração ao planejarem sua disciplina, pelo fato de não entendê-los.

Em minha análise pude notar que os PCNEM e PCN+ são documentos com vários pontos frágeis, e dificilmente darão subsídios necessários para os professores desenvolverem um trabalho de qualidade nas escolas.

Os documentos que os professores e as escolas públicas geraram não vêm ao encontro das capacitações básicas de que um aluno necessita para competir, em grau de igualdade, com os da escola particular, no esforço de conquistar uma vaga nas universidades públicas, nem de obter empregos que exijam qualificação.

As escolas particulares e cursos pré-vestibulares investigados, na falta de diretrizes ou parâmetros oficiais claros e coerentes, utilizam o programa do vestibular da UFPR para direcionar seu ensino, apesar do exame de inglês da UFPR ainda pautar grande parte de suas provas em uma visão ascendente de leitura. As públicas não conseguem operacionalizar os documentos oficiais e nem recorrem a qualquer outro tipo de documento que pudesse pautar um ensino de qualidade. O programa do vestibular de inglês da UFPR, na verdade, preenche esse vazio deixado pelo MEC e Secretaria Estadual e funciona como um currículo direcionador para escolas que têm um compromisso maior com seus alunos. Se as autoridades da educação tivessem uma preocupação em desenvolver um documento coerente para dar rumo ao ensino de língua inglesa no ensino médio, elas deveriam traçar diretrizes juntamente com a universidade, pois, como já citado anteriormente, um bom ensino deveria preparar seu aluno tanto para o trabalho e para a cidadania quanto para o ensino superior, não havendo essa polarização improdutiva entre ensinar para vida versus para vestibular. 


\subsubsection{Análise das provas de inglês do vestibular da UFPR}

As provas de línguas estrangeiras modernas do vestibular (inglês, francês, alemão, espanhol e italiano) evoluíram bastante desde 1972, quando foi realizado o primeiro concurso unificado da UFPR. As provas passaram por transformações em termos de concepção. De 1972 a 1995, eram elaboradas dentro dos paradigmas do período psicométrico-estruturalista e a concepção estruturalista da língua era perceptível nas questões de itens isolados de gramática. As questões que avaliavam a leitura eram embasadas na concepção behaviorista da linguagem, na qual o leitor era mero decodificador. O significado estava cristalizado no próprio texto e cabia ao candidato somente pinçar informações dele. Nessa época acreditava-se que a língua pudesse ser quebrada em pequenas unidades para ser ensinada/avaliada. A leitura era vista como uma extração de significado do texto, conhecido como modelo ascendente ou de decodificação.

Os adeptos dessa visão de linguagem negligenciavam aspectos culturais e sociais da língua e não a viam como um processo de negociação de sentidos entre o leitor-texto-contexto. A supremacia da avaliação da gramática sobrepujava a das outras habilidades. Podemos observar esse tipo de avaliação nas questões 36 e 37 do vestibular de 1976:

* Qual das alternativas abaixo contém a palavra "hardly" no lugar apropriado?

a) I had got hardly indoors when it started to rain.

b) I hardly had got indoors when it started to rain.

c) I had got indoors when it hardly started to rain.

d) I had got indoors when it started to rain hardly.

e) I had hardly got indoors when it started to rain.

A questão é do tipo de item isolado na qual o candidato tinha que saber apenas a ordem das palavras, ou seja, onde os advérbios de freqüência eram colocados na oração.

$* \mathrm{He}$ a lot of money last year.

I always my best.

It has nothing to with you.

This is all I have, will it

She him eat his dinner.

Preencha as lacunas com as palavras apropriadas e aponte a ordem obtida:

a) did make make made did d) made do do do made

b) did made do do makes e) made make make do did

c) did do do make did 
Esta segunda questão também é do tipo item isolado. O candidato tinha que saber a diferença entre os dois verbos em inglês que significam 'fazer'. Além disso, ele deveria saber conjugar esses verbos corretamente de acordo com outros segmentos que as orações ofereciam para demarcar tempo: last year (passado simples) na alternativa (a), always (presente simples) na alternativa (b), a marca gráfica do infinitivo em inglês, a palavra to, na alternativa (c), o will (futuro simples) na alternativa (d); e, por exclusão das outras alternativas, o passado simples na alternativa (e). Tanto a questão 36 como a 37 ilustram bem uma visão de língua estruturalista na qual podemos observar uma quebra do sistema lingüístico em pequenas unidades. Pressupunha-se que o aprendiz pudesse re-agrupar os fragmentos da língua para formar trechos maiores de textos falados/escritos.

Havia, no entanto, questões de compreensão de texto: pequenos trechos de textos "não autênticos", ou seja, escritos de maneira simplificada com o propósito didático e/ou de avaliação. Na maioria das questões, o candidato apenas tinha que "pinçar" uma informação do texto. Para responder às perguntas, tinha que decodificar a escrita, extraindo algumas informações isoladas.

Exemplo: questão 46 do vestibular 1976.

* Twenty years ago an old bachelor named Jack Hart, a man who had never shown interest in either religion or science, sat down alone in a rented room in Las Vegas, and wrote on a single page of a notebook his last will and testament. When he was finished, Hart placed the will in an envelope, sealed it, and then put it in his safe deposit box. A few years later he vanished without a trace.

O texto diz que:

a) Jack Hart morreu aos 20 anos.

b) Jack Hart parecia interessado em religião e ciência.

c) Jack Hart era formado em direito.

*d) Jack Hart era solteiro.

e) Jack Hart era muito rico.

Na questão acima, o candidato tinha que saber traduzir a palavra - falso cognato - bachelor, que quer dizer solteiro e não bacharel como em português. As alternativas $a, b$ e $c$ são compostas por descritores formados a partir 
de informações do texto que podem receber interpretações equivocadas por um leitor não proficiente. Na alternativa (a), por exemplo, o candidato tinha que identificar que Twenty years ago estava relacionado a um evento que havia acontecido há 20 anos (a escrita de um testamento por Hart e, posteriormente, seu desaparecimento); o texto não faz menção ao fato de Hart ter morrido e nem quando. $\mathrm{Na}$ (b), o leitor tinha que ter conhecimento gramatical: identificar a negação no present perfect (had never shown interest), ideia contrária ao do descritor. A alternativa (c) vale-se do falso cognato bachelor, favorecendo um equívoco de leitura em nível lexical. E, a última alternativa (e) pode ser considerada problemática, pois alguns elementos do texto podem levar o leitor a inferir que Hart tinha muito dinheiro: primeiro, somente pessoas que têm posses e dinheiro escrevem testamentos. Um segundo elemento é o fato de ele ter colocado o testamento em um cofre, caracterizando-o como um documento importante, de muito valor. Por último, Hart estava em Las Vegas, lugar relacionado aos jogos de azar, dinheiro e "glamour". Portanto, há indícios que levam o leitor a inferir que Hart talvez fosse mesmo rico e isso poderia levar vários candidatos a escolher a alternativa (e) e não a (d). A avaliação deste texto centrou-se apenas no léxico, sendo este um falso cognato. Na verdade, as alternativas tentam reproduzir "pedaços" do texto, de ordem puramente lingüística, focando elementos isolados. Trata-se, portanto, de uma avaliação centrada na língua e não na leitura em si.

A partir dos anos 80, as questões de itens isolados de gramática, descontextualizadas, deram lugar a questões baseadas em pequenos textos ainda não autênticos. Nessa época, o modelo de leitura era o descendente ou psicolingüístico e a ênfase do texto passa então ao leitor. Porém, ao invés de o exame ser adaptado ao novo modelo de leitura vigente, os textos das provas de vestibular serviam somente como pretexto para a fragmentação da língua continuar sendo explorada nas questões, desta vez, de múltipla-escolha somatória. As provas de língua inglesa do vestibular da UFPR permaneciam, portanto, com os atributos da era psicométrico-estruturalista, com uma visão de língua e leitura estruturalista ascendente, na qual o leitor/candidato tinha somente que pinçar as respostas no texto, tendo que, para isso, conhecer o léxico e a gramática da língua não como recursos expressivos, mas desconectados de suas funções lingüístico-discursivas. Exemplo: questões 16 a 19 do vestibular 1985 . 
A doctor was examining a lady who was no longer very young. She'd fallen down and had hurt her knee. The doctor wanted to be sure that that was all she'd hurt. 'Tell me,' he asked her casually, 'how old are you?'. 'Twenty-five' was the answer. The doctor wrote 'Loss of Memory' down on his notes.

Com base no texto acima, responder aos itens 16 a 19.

16 - The doctor was examining the lady because:

*01) She was hurt.

02) She had lost her memory.

04) She thought she was young.

*08) She had hurt her knees.

16) She was young.

*32) She had fallen down and had hurt her knee.

64) She didn't want to get old.

17 - The first sentence in the passage above means the same as:

01) A very young lady was being examined by a doctor.

02) It took the doctor a long time to examine the young lady.

*04) A lady who was no longer very young was being examined by a doctor.

08) It took the doctor longer to examine the old lady.

*16) A doctor was examining a lady who was not young any more.

18 - What is the full form of 'd in: She'd fallen down?

01) Did.

02) Could.

04) Would.

08) Should.

*16) Had

32) Led

19 - The reported form of the direct speech in the passage is:

01) The doctor asks her how old she is and she answers that she was twenty-five.

02) The doctor asks the lady how old she was and she answered the she was twenty-five.

*04) The doctor asked her how old she was and she answered that she was twenty-five.

08) He asked her how old you are and she answers that she is twenty-five.

16) He asked her how old she is and she answers that she was twenty-five.

*32) He asked her how old she was and the lady answered that she was twenty-five.

64) He asks her how old she was and the lady answered that she is twenty-five. 
Na questão 16, o candidato tinha apenas que identificar que a senhora de quem se fala no texto tinha machucado o joelho em uma queda. Para isso era preciso somente reconhecer a oração "She'd fallen down and had hurt her knee". As alternativas corretas (1) She was hurt, (8) She had hurt her knees, e (32) She had fallen down and hurt her knees são variações simples da oração original do texto. Na questão 17 , o candidato tinha que fazer exatamente o que fez na alternativa anterior: somente recuperar uma pequena informação na primeira oração. Ao decodificar a primeira oração do texto $A$ doctor was examining a lady who was no longer very young, o candidato tinha que reconhecer a transformação da voz passiva da oração original do texto (04) e observar uma variação sintática na alternativa (16), oração este muito próxima da original. Esta questão se limitou em avaliar a sintaxe e o léxico, desconsiderando seu funcionamento no texto enquanto um todo. Os elaboradores do exame deixaram de lado uma boa oportunidade de avaliar a capacidade do candidato de reconstruir a anedota que poderia ser inferida no texto: a senhora mentiu sobre sua idade avançada e o médico a diagnosticou com problemas de memória uma vez que ela não "se lembrava" de sua verdadeira idade.

Nas questões 18 e 19, os elaboradores usaram o texto apenas como um pretexto para avaliar itens gramaticais isolados. Na questão 18, o candidato tinha que saber que ' $d$ em She'd fallen down era uma contração do auxiliar had do "past perfect" do verbo fall down. Na 19, o candidato tinha que transformar duas orações (How old are you? e I'm twenty-five) do discurso direto para o indireto, considerando o tempo verbal introdutório asked. As alternativas corretas são (04) e (32). As únicas diferenças entre elas são o uso dos pronomes he para the doctor e she para the lady. Não há nenhuma preocupação em se avaliar a compreensão e como esses itens gramaticais funcionam no texto considerando-se uma construção de sentido(s). A avaliação do conhecimento gramatical fragmentado continua com sua supremacia a partir de pequenos textos simplificados e não autênticos.

A partir de 1995, no entanto, as provas de língua inglesa ${ }^{6}$ sofreram alterações na medida em que a leitura passou a ser o foco. Os textos didáticos simplificados deram lugar a textos "autênticos", de fontes diversas: jornais, revistas, Internet, privilegiando-se gêneros jornalísticos, de divulgação científica e acadêmicos. Algumas questões continuaram a ser escritas em inglês e outras em português, embora em número reduzido. A formulação da questão

6 As provas de inglês do vestibular da UFPR de 2000 a 2006 foram incluídas na íntegra no Anexo C. 
em língua estrangeira pode gerar um problema na avaliação da leitura do texto, isto é, um problema de validade de construto: com as questões em inglês, o leitor/candidato tem diante de si um outro texto em língua estrangeira, que deve ser bem compreendido e interpretado. Em caso de respostas inadequadas, como garantir que o problema se limitou a uma compreensão equivocada do texto? Em que medida a "não compreensão" da "instrução" (do texto da própria pergunta) poderia ser um fator "perturbador" na leitura do texto? Qual construto estaríamos avaliando: a compreensão da questão ou do texto? Se o que se pretende com o instrumento de avaliação é avaliar o grau de compreensão da leitura de um texto, tanto a formulação da pergunta como a resposta (aberta no caso de um exame dissertativo) ou alternativas (no caso de múltipla-escolha) não podem ser avaliados e, portanto, devem ser em língua materna.

Os tipos de textos escolhidos para as provas de língua inglesa giram em torno de alguns temas: comportamento (No play? No Was! - 2000, Teenagers Do Their Talking Online - 2002, TV Addiction - 2003, Battle over Texas sex-ed Textbooks - 2004); atualidades veiculadas na imprensa escrita (Executions by Regions - 2000, Soccer World Cup - 2002, Suspected Thief Drowns -2003, Genius, Criminals Do Best Work in Their 30's - 2004, After Katrine, family is reunited, but homes were destroyed - 2006); saúde (A Heads upon Headers - 2000, Flood-stricken Czech plan mass-vaccination - 2003, Male contraceptive, 100\% effective - 2004, What causes headaches? -2005); história (Pyramids in Mexico - 2000, A Century of Mathematics, - 2000); meio ambiente (Why hurricanes hit in summer, early fall-2000, Is Global Warming Harmful to your Health? - 2002). Os textos são, geralmente, de vulgarização científica, de assuntos atuais que estão na mídia, extraídos das fontes Scientific American WEB edition, USA Today, Time for Kids. Ocasionalmente, percebem-se outros gêneros tais como, gráfico (vestibular 2000), anúncios publicitários (vestibular 2001), notícias de jornal/revista (vestibular 2002) ou de sites da Internet (vestibulares 2003, 2004, 2005 e 2006). No vestibular de 2003, um trecho de bate-papo da Internet foi incluído. Trata-se de textos predominantemente pertencentes ao universo de leitura dos leitores/ candidatos, pois é o que se imagina pertinente como leitura de alunos egressos do ensino médio, pleiteando uma vaga para iniciar seus estudos universitários. O que se espera desses leitores é que eles estejam aptos a lerem criticamente notícias da atualidade (cidadãos bem informados) bem como preparados para iniciarem leituras acadêmicas (textos de divulgação científica, exerceriam uma função de "introdutórios" para tal fim). A mudança de tipos de textos constatada acima reflete uma concepção de leitura como uma prática social. Porém, como veremos a seguir, apesar da mudança de tipos de texto, não houve mudanças 
significativas em relação aos projetos de leituras propostos pelas questões, que ficaram presas ao modelo ascendente de leitura.

Em algumas provas há, ao final de cada texto, um glossário com o vocabulário que o examinador julga ser mais complexo para o leitor/candidato. A presença de glossário em uma prova de leitura é bastante pertinente, desde que seja bem elaborado e considerando-se o grau de "familiaridade" do léxico com relação ao perfil do leitor/candidato e a possibilidade de inferência de significado a partir do contexto em que aparece.

Porém, algumas palavras escolhidas para integrar o glossário poderiam ser inferidas, o que pode sugerir que não está em jogo a avaliação de inferências de significados de palavras desconhecidas a partir do contexto: uma estratégia desejável que um bom leitor desenvolva. Um exemplo é encontrado na prova de 2002:

\section{Teenagers Do Their Talking Online Jeff Palfini \\ Thursday, June 21, 2001}

Today's teens communicate more using the Internet than they do face-to-face. Their parents' generation fought to use the family phone. Today's teens fight over the Keyboard.

A new study by the Pew Internet e American Life Project says teenagers have adopted the Internet - and instant messaging - so completely that it has even replaced face-to-face communication as the primary mode of interacting for some teens. The study concluded that of the approximately 13 million American teenagers who use the Net, 74 percent use instant messaging. Surprisingly, onefifth of the teens using IM say it is their primary means of communicating with friends. The study extrapolated the results from a survey of 754 youngsters between the ages of 12 and 17 and their parents.

\section{Vocabulário}

primary = principal, mais importante

O léxico escolhido para integrar o glossário foi 'primary' que apesar de ser considerado um falso cognato nesse contexto - primeiro, elementar, mais importante e não primário - poderia ter sido inferido a partir do contexto.

Até 2004, os exames eram constituídos de dez questões. O número de textos por exame varia de dois a quatro. A partir de 2005, o número de questões foi reduzido para oito. Para que pudéssemos analisar as questões dos exames de 2000 a 2006, foi necessário, primeiramente, adotarmos uma taxonomia 
de questões. Optamos por aquela desenvolvida por Cherem e Nery (1993) e Nery (2003).

Observou-se que todos os exames desse período possuem um maior número de questões do tipo reconstituição da informação pontual linear. Notou-se que as provas de múltipla-escolha simples levam à elaboração de questões desse tipo, ao passo que as de múltipla-escolha somatória levam a questões do tipo reconstituição da informação pontual não linear. Vejamos alguns exemplos do tipo reconstituição de informação pontual linear nas questões 77 a 79 do exame de 2005:

As questões 77 a 80 referem-se ao texto a seguir.

\section{Battle over Texas sex-ed textbooks}

Texas educators are debating what will be taught in new sexual education textbooks for its high school students. The 15-member Texas Board of Education is considering and will likely approve four books, all of which extol the virtues of abstinence. Three make no mention of contraceptives at all while one makes passing reference to condoms.

Critics are crying foul, saying that a lesson of abstinence alone is dangerous because it could lead to more teen pregnancies and more teens becoming infected with sexually transmitted diseases.

The battle in Texas has national implications because the state is the secondbiggest market for textbooks in the United States. Books approved by the state's school board are typically marketed nationally.

According to Centers for Disease Control figures, Texas has been among the top five states in the country for teenage pregnancies for several years.

When he was governor of Texas, George W. Bush pushed for abstinence-based sexual education curriculum. He raised his concerns to a national level when he said in this year's State of the Union address: "We will double federal funding for abstinence programs so schools can teach this fact of life: Abstinence for young people is the only certain way to avoid sexually transmitted diseases."

National surveys indicate that a wide majority of parents support a strong abstinence message to teens in sexual education. The Texas Freedom Network, a group that regularly battles social and religious conservatives in the state, along with Planned Parenthood and others are asking the board not to approve the four textbooks under consideration.

Disponível em: <http://www.cnn/2004/EDUCATION/Texas.textbooks.reut/index. html>. Acesso em: 06 ago. 2004. 


\section{7 - According to the text:}

*) "The only safe sex is no sex" may become the lesson for Texas teens and for the rest of the US.

-) The sexual education textbooks that the Texas Board of Education will probably approve contain detailed information about contraceptives such as condoms.

-) High school students are engaged in a debate about the sexual education textbooks that are going to be used in schools in Texas.

-) The Texas Board of Education has little concern about the new sexual education textbooks high school students will be using.

-) None of the new sexual education textbooks has information on contraceptives.

78 - According to the text:

*) George W. Bush has been in favor of a curriculum that supports abstinence among teenagers.

-) George W. Bush does not want the new sexual education textbooks to get approval because they are too conservative.

-) In his State of the Union address, George W. Bush aimed at promoting the general welfare of children from all over the world.

-) George W. Bush thinks there should be fewer federal investments to avoid sexually transmitted diseases.

-) George W. Bush believes that the main contraceptive methods should be included in school curriculum all over the US.

79 - The four textbooks likely to be approved

*) contain almost no information about the prevention of sexually transmitted diseases other than through abstinence.

-) advise that a good way a teenager can prevent sexually transmitted diseases is to get plenty of rest.

-) indicate the necessity of conducting national surveys to investigate if parents support the idea of teaching abstinence.

-) have the support of The Texas Freedom Network, which is a conservative religious group.

-) offer comprehensive detail about teenage pregnancies in Texas in the last few years.

Para o leitor/candidato responder à questão 77, não é necessário ler o texto todo. Basta que ele recupere informações contidas nas segunda e terceira 
orações do primeiro parágrafo do texto: "The 15-member Texas Board of Education is considering and will likely approve four books, all of which extol the virtues of abstinence. Three make no mention of contraceptives at all while one makes passing reference to condoms". Mesmo que o leitor/ candidato não saiba o significado da palavra "extol" (elogiar, exaltar), ele pode inferi-lo quando compreende que "virtues of abstinence" são 'as virtudes da abstinência'. Isso ocorre pelo fato das palavras serem transparentes, ou seja, similares às do português. Na segunda oração, "no mention of contraceptives" (sem menção aos contraceptivos) também pode ser facilmente compreendido em virtude da transparência das palavras. E na alternativa correta, basta o leitor/candidato compreender "safe sex is no sex" (sexo seguro é sem sexo) para ele conseguir acertar a questão pontualmente.

Na questão 78, a resposta está contida na primeira oração do quinto parágrafo: "When he was governor of Texas, George W. Bush pushed for abstinence-based sexual education curriculum". Nessa oração, se o leitor/candidato inferir o significado das palavras "pushed for" (insistir), a partir do contexto, o restante pode ser deduzido, se ele relacionar as palavras transparentes com o português "abstinence-based sexual education curriculum" (currículo de educação sexual baseado em abstinência). Na alternativa correta, o leitor/candidato também deve concluir que "in favor of a curriculum... abstinence among teenagers" seja (a favor de um currículo... abstinência entre os adolescentes) a partir da transparência das palavras.

A resposta à questão 79 aparece pontualmente também, no segundo parágrafo. O leitor/candidato deve compreender "lesson of abstinence alone is dangerous" (somente lição de abstinência é perigoso) e "more teens becoming infected with sexually transmitted diseases" (mais adolescentes podem ser infectados com doenças sexualmente transmitidas) para concluir do enunciado da alternativa (a) que "no information about the prevention of sexually transmitted diseases" (não contém informação sobre prevenção de doenças sexualmente transmissíveis).

As três questões são do tipo reconstituição da informação pontual linear e, portanto, no pólo máximo da facilidade, limitando-se ao reconhecimento, não avaliando compreensão. Elas exigem que o leitor/candidato pince informações pontual e linearmente no texto. Além das respostas serem facilmente localizadas no texto, o leitor/candidato conta com a transparência da maioria das palavras que são similares às do português. A avaliação de leitura foi limitada a um nível simples de decodificação das palavras (elementos ligados 
a léxico e morfo-sintaxe, portanto, ao nível da frase enquanto estrutura isolada, independente da tessitura geral do texto), não cobrando um sentido pleno de leitura como construção de significados. Uma questão que poderia ter sido feita para avaliar-se efetivamente a leitura, ou seja, a compreensão do texto enquanto um todo significativo, seria, por exemplo: qual a posição do autor em relação à inclusão das virtudes da abstinência sexual em livros didáticos; de quais argumentos ele se utiliza para dar suporte a sua opinião? Essa questão suscitaria uma leitura global do texto, exigindo, de forma não orientada, a reconstrução da cadeia argumentativa.

No texto seguinte, pertinente à prova do vestibular 2002 - questão n. 3 - podemos observar uma questão do tipo reconstituição da informação global e de ordenação e relevância. Nesse tipo de questão global, o leitor/candidato deve realizar 'uma operação de atribuições de sentido que atua sobre o texto em sua globalidade', ou seja, em todo o texto, e não somente num determinado ponto dele, como no pontual, quando a pergunta incide apenas sobre um aspecto particular do texto. Além disso, o leitor/candidato necessita reconstituir a ordenação de informações a partir do grau de relevância delas. Apesar de se tratar de um texto com predominância informativa e da questão incidir sobre informações contidas no texto (sendo portanto do tipo reconstituição de informação), ela é global, envolvendo, portanto, uma reconstrução da cadeia argumentativa que perpassa pelo texto todo. Tem-se aí, portanto, outros tipos de questão imbricados: ordenação e relevância e reconstrução da argumentação sendo ambos, nesse caso, do tipo global, ou seja, três fatores que constituem a complexidade desta questão, apesar de ela ser, de certa forma orientada (pelo fato de ser teste de múltipla-escolha: diferentes leituras já foram dadas).

\section{Is Global Warming Harmful to Health?}

Paul R. Epstein

\section{Computer models indicate that many diseases}

will surge as the earth's atmosphere heats up.

Today few scientists doubt the atmosphere is warming. Most also agree that the rate of heating is accelerating and that the consequences of this temperature change could become increasingly disruptive. Even high school students can reel off some projected outcomes: the oceans will warm, and glaciers will melt, causing sea levels to rise and salt water to inundate settlements along many lowlying coasts. Meanwhile the regions suitable for farming will shift. 
Yet less familiar effects could be equally detrimental. Notably, computer models predict that the greenhouse effect, and other climate alterations it induces, will expand the incidence and distribution of many serious medical disorders. In some places, the number of deaths related to heat waves is projected to double by 2020. Prolonged heat can, moreover, enhance production of smog and the dispersal of allergens. Both effects have been linked to respiratory symptoms. Diseases relayed by mosquitoes - such as malaria, dengue fever, yellow fever and several kinds of encephalitis - are among those eliciting the greatest concern as the world warms. Some models project that by the end of the 21st century, ongoing warming will have enlarged the zone of potential malaria transmission from an area containing 45 percent of the world's population to an area containing about 60 percent. That news is bad indeed, considering that no vaccine is available and that the causative parasites are becoming resistant to standard drugs. Further, global warming will probably elevate the incidence of waterborne diseases, including cholera (a cause of severe diarrhea).

The consequences of global warming may not all be bad. Very high temperatures in hot regions may reduce snail populations, which have a role in transmitting schistosomiasis, a parasitic disease. High winds may at times disperse pollution. Hotter winters in normally chilly areas may reduce cold-related heart attacks and respiratory ailments. Yet overall, the undesirable effects of more variable weather are likely to include new stresses and nasty surprises that will overshadow any benefits. (Adapted from Scientific American, Aug. 2001)

\section{Vocabulário}

disruptive $=$ disturbing; to disrupt $=$ to cause disorganization

reel off = dizer de cor e salteado

outcomes $=$ final results

enhance $=$ increase

snail = caracol

likely $=$ probable

nasty = very bad

\section{3 - What information is in the text?}

F) Some of the causes of global warming.

V) Some negative consequences of global warming.

F) The percentage of people who will have contracted malaria by the end of this century.

F) The number of people who will have died due to heat waves by 2020 .

V) Some positive consequences of climate warming.

V) Some of the projections made by computer models. 
Para que o leitor/candidato possa responder à questão, tem que recuperar informações ao longo do texto. Por exemplo, para que ele possa entender as conseqüências negativas do aquecimento global (segunda alternativa: "some negative consequences of global warming") deve reconstruir a argumentação contida nos primeiro, segundo e terceiro parágrafos. No primeiro parágrafo, a conseqüência negativa é que os oceanos irão esquentar e geleiras derreterão, causando um aumento no nível do mar e a água salgada inundará lugares habitados ao longo das áreas baixas das costas (oceans will warm, and glaciers will melt, causing sea levels to rise and salt water to inundate settlements along many low-lying coasts). No segundo, o autor expõe efeitos negativos menos conhecidos, mas que são igualmente prejudiciais, como o aumento de incidência e a distribuição de doenças sérias em razão das alterações climáticas, do aumento de produção de poluição do ar e da dispersão de alergênicos devido às prolongadas ondas de calor. Ambos exemplos de conseqüências negativas têm efeitos ligados aos sintomas respiratórios (other climate alterations it induces, will expand the incidence and distribution of many serious medical disorders. In some places, the number of deaths related to heat waves is projected to double by 2020. Prolonged heat can, moreover, enhance production of smog and the dispersal of allergens. Both effects have been linked to respiratory symptoms). No terceiro parágrafo, o autor continua a dar exemplos de conseqüências negativas do aquecimento global menos conhecidas, como o aumento de mosquitos transmissores de malária, dengue, febre amarela, e vários tipos de encefalites. Haverá um aumento de área de transmissão de malária e haverá uma elevação de incidências de doenças causadas por água como a cólera (Diseases relayed by mosquitoes - such as malaria, dengue fever, yellow fever and several kinds of encephalitis ... ongoing warming will have enlarged the zone of potential malaria transmission... global warming will probably elevate the incidence of waterborne diseases, including cholera).

As conseqüências positivas do aquecimento global podem ser reconstituídas no último parágrafo. A questão requer que o leitor/candidato compreenda que as conseqüências positivas do aquecimento são que a população de caramujos pode reduzir-se e isso pode ter um papel importante na transmissão de esquistossomose; fortes ventos podem dispersar poluição e invernos mais quentes podem reduzir ataques cardíacos relacionados ao frio e doenças respiratórias (The consequences of global warming may not all be bad... may reduce snail populations which have a role in transmitting schistosomiasis a parasitic disease", "High winds may at times disperse pollution.... 
Hotter winters in normally chilly areas may reduce cold-related heart attacks and respiratory ailments).

Porém, o aspecto mais importante do texto é desprezado, ou seja, a tese central do autor. Apesar de o aquecimento global propiciar algumas conseqüências benéficas para o meio ambiente, os efeitos maléficos, somados aos que ainda virão à tona, sobrepõem-se a todos os efeitos positivos. Formular uma pergunta cuja resposta o leitor/candidato tivesse que, sozinho, apreender essa tese, somente seria possível em uma prova dissertativa.

As duas primeiras alternativas corretas da terceira questão induzem o leitor/candidato a procurar informações espalhadas no texto - trata-se, portanto, de orientação - e a última alternativa correta é do tipo reconstituição da informação pontual linear, pois a resposta é pinçada da segunda oração do segundo parágrafo: "Notably, computer models predict that the greenhouse effect".

Algumas questões do tipo estabelecimento de relações foram encontradas. Apresentamos como exemplo a questão a 74 do vestibular 2005. Podemos observar que a pergunta exige que o leitor/candidato reconheça uma referência anafórica. Trata-se, nesse caso, de estabelecer uma relação entre um elemento do texto (um segmento contendo uma anáfora) e uma frase que imediatamente o antecede. Envolve, portanto, uma relação que não extrapola o nível da frase, incidindo sobre um aspecto de coesão importante para a leitura, mas que, nesse caso, foge ao que se espera de uma questão desse tipo: a não linearidade. Tem-se aí, um caso típico: relação pautada na linearidade do texto. Mais uma vez, avalia-se mais o reconhecimento do que a compreensão.

\section{What causes headaches?}

Mike A.

Wilmington, Del.

Dawn A. Marcus, an associate professor at the University of Pittsburgh School of Medicine's department of anesthesiology, explains.

When experiencing a severe, throbbing headache, a person often places his hands on both sides of his head and claims, "It feels like my brain is pushing to get out, so it feels better to hold it in." This sensation gives a false impression that the brain itself is enlarging and causing the pain sensation. Interestingly, brain tissue does not feel pain in the same way skin or other organs do. Because the brain is encased in a hard protective covering, it has not developed to respond to touch or pressure sensations like other, more exposed parts of our bodies have. Indeed, a brain surgeon can actually cut brain tissue in an awake patient without the patient feeling the knife.

Disponível em: <http://www.sciam.com>. Acesso em: 06 ago. 2004. 
74 - In the sentence "This sensation gives a false impression that the brain itself is enlarging and causing the pain sensation" the underlined words refer to:

*) the sensation that the brain is pushing to get out.

-) the sensation that the headache is severe.

-) the sensation that placing hands on both sides of the head can increase pain.

-) the sensation of relief after overcoming pain.

-) the sensation that it feels better to hold the brain in.

Para responder à questão, o leitor/candidato tinha que estabelecer uma relação entre o demonstrativo this, em this sensation (esta sensação) com a oração que a antecede: parece que meu cérebro está tentando sair (it feels like my brain is pushing to get out).

Uma questão de estabelecimento de relação que poderia ter sido feita seria relacionar o título à argumentação do texto. Por exemplo, responder à pergunta do título do texto - O que causa dor de cabeça? (What causes headaches?). O leitor/candidato teria que compreender todo texto para poder estabelecer uma relação do conteúdo do texto e responder à pergunta do título. A própria natureza do exame - limitações que a múltipla-escolha impõe - impede que o leitor/candidato faça sozinho a reconstrução da argumentação do texto para poder responder à pergunta do título.

No vestibular de 2003, foi percebida uma questão do tipo reconhecimento do quadro enunciativo. Nesse tipo de questão, o leitor/candidato teria que reconhecer os componentes da cena enunciativa (ou seja, como o sujeito que enuncia e como o sujeito a quem enuncia se constituem na configuração discursiva) e compreender as estratégias discursivas a que se prestam" (NERY, 2003).

\section{Suspected Thief Drowns}

Sun Aug 18, 7:35 AM ET

TULSA, Oklahoma (Reuters) - A suspected thief, weighed down with more than 50 pounds of stolen cameras and CDs, among other items, drowned as he attempted to evade police by swimming across the Arkansas River, officials said.

The man, identified as Edward McBride, 37, was carrying a bag weighing 50 pounds that contained stolen items and was found Friday with stolen goods also stuffed in his pockets, said Tulsa police spokesman Lucky Lamons.

He was being pursued by Tulsa police who suspected him of robbing a Tulsa home when he jumped into the muddy Arkansas River. 
"He got about 40 yards out and yelled for help," Lamons said. "The officers took off their shirts, shoes and belts and jumped into the river. By the time they reached him, he had gone under."

Lamons said rescue workers retrieved McBride's body about an hour later from about 8 feet to 10 feet of water along with the bag containing stolen goods.

Disponível em: <http://story.news.yahoo.com/news? tmpl= story2ecid $=573 \mathrm{ee}=$ 4 eu=/nm/20020818/od_nm/drowning_dc_1 >. Acesso em: 19 ago. 2002.

5 - De acordo com o texto acima, é correto afirmar:

F) Ao fugir da polícia, McBride caiu involuntariamente no rio.

V) McBride tinha 37 anos e era suspeito de ter assaltado uma casa.

V) O peso dos objetos roubados que carregava consigo contribuiu para o afogamento de McBride.

F) McBride se especializava no roubo de joias e quadros.

F) McBride foi retirado do rio ainda com vida, mas morreu logo em seguida.

V) Os fatos narrados ocorreram no mês de agosto, em Tulsa, no estado americano de Oklahoma.

Na última alternativa, o leitor/candidato deveria identificar que o roubo ocorreu em agosto, na cidade de Tulsa, no estado americano de Oklahoma, ou seja, ele deveria reconhecer que o texto era uma notícia de jornal (no caso, virtual da agência de notícias Reuter), escrita para os leitores que têm acesso ao meio eletrônico. Além da questão ser do tipo reconhecimento do quadro enunciativo, ela não deixa também de ser do tipo reconstituição de informação pontual não linear.

A primeira alternativa correta - McBride tinha 37 anos e era suspeito de ter assaltado uma casa. - exigia que o leitor/candidato reconstituísse informações pontuais não lineares, pois ele tinha que localizar no texto informações, tais como um suspeito ladrão afundou com mais de 50 libras de câmeras e CDs roubados dentre outros itens (A suspected thief, weighed down with more than 50 pounds of stolen cameras and CDs, among other items), e a idade do ladrão no segundo parágrafo - um homem identificado como Edward McBridge, 37... (The man, identified as Edward McBride, 37).

A segunda alternativa correta - O peso dos objetos roubados que carregava consigo contribuiu para o afogamento de McBride - é um outro exemplo de reconstituição de informação linear. Basta que o leitor/candidato entenda somente o primeiro parágrafo.

Já questões do tipo apreensão de julgamento de valor, quando o leitor/ candidato necessita apreender segmentos do texto que veiculam um julgamento de valor que se apresenta como tal, foram percebidas em poucos vestibulares: 2001, 2003 e 2005. 
Um exemplo são as questões 16 e 17 do vestibular 2001.

\section{Why we don't vote}

Jim Lehrer, who is anchoring the presidential debates this year, boasts that he has not voted since the 1960s. Len Downie, editor of The Washington Post, declines to cast a ballot and doesn't want his political reporters voting either.

If you want to know why political participation is off sharply in this country, here's one reason: The intellectual elites look down on the process. Voting is for the masses, they seem to be saying, not us big thinkers. We have better things to do.

I know, Lehrer and Downie justify their views on the ground that reporters should be unbiased. But that, to put it politely, is hogwash. Journalists are citizens, too. We like to think, in fact, that we're central to a healthy political process So how, then, can we avoid the most essential political act of all? What kind of message does that send to our readers and viewers?

Recent figures are startling. According to the Committee for the Study of the American Electorate, only 36.1\% of the eligible voting-age population exercised their rights in 1998. That's the lowest figure in a non-presidential year since many young. Americans were off fighting overseas in 1942. In the last presidential election year, 1996, barely half the eligible voters bothered to show up.

The disdain of the non-voting elite is only a small part of the problem. Journalists contribute to the trend in another, larger way: We tend to cover politics by exaggerating extremes, emphasizing mistakes and highlighting corruption. The picture we draw is often a cartoon, not reality. (Steven Roberts, USAToday, October 9, 2000)

16 - In the author's opinion, journalists are partly responsible for the low political participation because:

*01) They don't vote and, in so doing, they send the wrong message to their readers and viewers.

*02) They depict politicians and the political process in a distorted way.

04) They defend the idea that it is useless to vote, because nothing will change.

08) Their views are so clearly partial in favor of one candidate or another that the readers don't know who to believe.

16) The political analyses written by journalists are so complex that the masses don't understand them.

03

17 - In this text, the author

*01) presents some data about the political participation in the United States.

02) agrees with the view that in order for journalists to be impartial, they should abstain from voting.

*04) shows his dissatisfaction about voters' turnout in the United States.

08) agrees with the view that voting should be for the masses.

16) shows disdain for those who vote. 
No texto, o autor faz uma severa crítica à elite intelectual americana que deixa de votar, especialmente os jornalistas que justificam seus atos em nome da imparcialidade política. Ele assevera que o desdém dessa elite não votante ao processo eleitoral, além de ser um mau exemplo para um eleitorado que vota cada vez menos, faz questão de reforçar somente os erros e corrupção do meio político, o que acaba contribuindo para criação de uma visão exagerada e caricaturada dos políticos e da política. Na questão 16, o elaborador buscou suscitar uma resposta para a qual se exigia dos leitores/candidatos apreensão de julgamento de valor. As alternativas corretas, "eles não votam e, fazendo isso, eles mandam uma mensagem errada aos leitores e espectatores" (They don't vote and, in so doing, they send the wrong message to their readers and viewer.) e "eles descrevem os políticos e o processo político de uma maneira distorcida" (They depict politicians and the political process in a distorted way, ), apontam para a opinião do autor em relação à abstenção do ato de votar.

Na questão 17, a segunda alternativa também exige que o leitor/candidato apreenda um julgamento de valor: o autor mostra sua insatisfação a respeito do número de eleitores que votam nos Estados Unidos (the autor shows his dissatisfaction about voters' turnout in the United State.)

No vestibular de 2003, o elaborador trabalhou também com algumas questões do tipo apreensão de julgamento de valor a partir de um texto sobre a Copa do Mundo, contendo diversas opiniões dos internautas em um fórum no site da BBC.

\section{INGLÊS}

Logo após o encerramento da Copa do Mundo de futebol, internautas de várias partes do mundo apresentaram seus comentários em um forum no site da $B B C$.

Well done, Germany! They did so well. It was unlucky to be defeated in the final. Although Kahn is not on the winning side, he is my best player in the tournament. And I have to mention that all the Germans did give me big surprises when nobody, including myself, believed they could reach the final one month ago.

Anyway, the Germans have showed they are the best European team in 2002. I look forward to the World Cup 2006 and I believe that they will be stronger and stronger.

Victor, Australia 
Oliver Kahn did quite well; the first goal was not all his fault. Hamman dwelled on the ball to long and paid for it. Kahn kept Germany in the game many times. If it was not for him, Germany would have lost by many more.

\section{Timmy Deavin, England}

Damn Oliver Kahn! I thought he was a descent goalie but he disappointed me in both goals he conceded and I've lost faith in him. But as a team I'm proud of how Germany played.

\section{Tibor, Australia}

The 2-0 result today does not show how well Germany played today. Oliver Kahn should not be blamed for the first goal; the ball had been well driven by Rivaldo. It was a difficult ball for even a great Keeper like Kahn to stop without a rebound.

Mike, USA

It was Germany's best performance of the World Cup - but this time the luck ran out. No one can deny that the best team won the tournament.

\section{Les, Germany}

Olli Kahn deserves the title of best player on the World Cup. Although he made a mistake he was the man that brought Germany thus far in the tournament, much as Ronaldo did with his men.

\section{Matthias, Germany}

Disponível em: <http://news.bbc.co.uk/sport3/worldcup2002/hi/sports_talk/ newsid_1921000/192183.stm>. Acesso em: 1 jul. 2002.

Q 1 - Quanto às opiniões sobre a atuação do goleiro Oliver Kahn, é correto afirmar:

V) Para Victor, da Austrália, Kahn foi o melhor jogador da Copa.

F) O internauta identificado como Tibor, da Austrália, afirma que Kahn jogou muito bem.

V) Para Matthias, da Alemanha, Kahn foi o grande responsável por seu país ter chegado até onde chegou.

F) Para Matthias, da Alemanha, a atuação de Kahn foi perfeita.

F) Todos os participantes do fórum elogiam a participação do goleiro alemão, mesmo os que admitem que ele possa ter falhado no primeiro gol da final.

Q 2 - In relation to the comments selected above, it is correct to say:

V) Les, from Germany, believes Brazil deserved to win.

V) Mike, from the US, is of the opinion that Germany played well.

V) Timmy Deavin, from England, believes that if it was not for Kahn, Brazil could have won by a greater margin.

F) Victor, from Australia, was disappointed at the German team.

F) Matthias, from Germany, thought Ronaldo's performance was disappointing. 
Em 2005, na questão 80 sobre o texto "Battle over Texas Sex-ed Textbooks" (ver texto pág. 157), aparece esse tipo de questão, quando se pediu para o leitor/candidato apreender que "os membros do conselho de educação mostram uma tendência de aprovarem livros com uma visão conservadora" (The members of the Texas Board of Education show a tendency to approve books which have a conservative view).

Porém, em muitos exames o elaborador desperdiçou alguns momentos excelentes para trabalhar com questões do tipo apreensão de julgamento de valor. Em 2000, no texto No Play? No Way!, poderia ter sido perguntado a posição do autor em relação à vida atribulada das crianças modernas. Por exemplo, justificar o título - No Play? No way! - que sintetiza a opinião do autor.

\section{No Play? No Way!}

School, sports, music lessons, dinner, homework, then bed. Sound familiar? If your schedule is this tightly packed, you're not alone. Last week, researchers announced that today's kids are the busiest ever. Kids used to have much more free time to play tag or build a snowman. In 1981 playtime made up 40\% of a child's day. That figure has dropped to $30 \%$, according to researchers at the University of Michigan. They conducted a study of more than 3,500 kids under age 13. Now kids spend more time at school and on homework. Out of school, more kids take part in organized activities, such as ballet or soccer. One finding that parents will surely love: kids are too busy to watch as much TV as they did in 1981! (TIME For Kids, 1999)

11 - The text above is about:

01) the problem kids have when they watch too much TV.

*02) the findings of a research conducted at the University of Michigan.

04) parents' daily schedule.

08) the changes in parents' organized activities.

*16) the decrease of children's playtime over the years.

18

12 - According to the text:

*01) Today's kids have a tightly packed schedule.

*02) There has been a reduction in the percentage of kids' free time over the last 18 years.

04) 3,500 kids under age 13 spend more time on ballet and soccer than at school and on homework. 
*08) Parents in general do not like their children to watch too much TV.

16) Kids used to spend less time watching TV in 1981 than they do nowadays.

13 - What information is in the text?

*01) A sequence of activities that can be considered a tightly packed schedule.

*02) The percentage of daily playtime that kids have nowadays.

*04) The institution which conducted the research.

*08) Examples of organized activities children do out of school.

16) The name of the researchers who conducted the study.

15

Em 2001, o título - Physicians, Heal Thyself - novamente poderia ter sido explorado para que o leitor/candidato apreendesse a posição do autor.

\section{Physician, Heal Thyself}

When the topic of medical errors comes up, people usually think of the most outrageous mistakes: the Florida doctor, for example, who amputated the wrong leg of his diabetic patient or the Colorado boy who died during ear surgery because his anesthesiologist allegedly fell asleep. Though much publicized, these egregious errors are relatively rare. Far more common are mental lapses or simple slip-ups that sometimes lead to disaster. For instance, a harried doctor misdiagnoses a patient because he cannot spend more than five minutes examining her. Or a pharmacist dispenses the wrong drug because he misreads the doctor's handwriting on the prescription.

Last fall the national Academy of Science's Institute of Medicine released a report entitled "To Err is Human," which claimed that between 44,000 and 98,000 Americans die every year as a result of medical errors. Even the lower estimate would make errors the eighth leading cause of death, striking down more people than motor vehicle accidents or breast cancer. The report outlined a series of recommendations aimed at reducing medical errors by 50 percent over the next five years. It advocated an approach similar to that used by the aviation industry, with the focus on collecting information on errors and using this knowledge to devise safer systems and procedures. President Bill Clinton has already endorsed the report, and Congress may act on several of its recommendations this year. (Scientific American, May 2000) 


\section{1 - The text contains:}

*01) examples of medical errors that have received a lot of attention in the media.

02) data related to the number of lawsuits brought about by medical errors.

*04) data related to the number of deaths caused by medical errors.

08) examples of problems that may result from minor errors on the part of health professionals.

16) data related to the social class of the victims of medical errors.

05

\section{2 - According to the text, it is correct to say:}

01) Health professionals become outraged when the issue of medical error emerges.

02) Surgeons make more mistakes than anesthesiologists.

*04) The difficulty in reading the physician's handwriting on a prescription may lead a pharmacist to hand out the incorrect medication.

08) Anesthesiologists are responsible for most medical errors.

*16) Doctors may make mistakes when they examine their patients in a hurry. 20

13 - According to the text, it is correct to say:

01) The report "To Err is Human" is based on data from the last five years.

*02) The report “To Err is Human' contains recommendations on how to reduce the incidents of medical error.

04) Due to the adoptions of the report recommendations, the number of medical error has dropped 50\%.

08) On the basis of the report, the American Congress has already passed new legislation intended to reduce the umber of deaths resulting from medical errors.

*16) The number of deaths due to medical errors is higher than the number of deaths resulting from motor vehicle accidents.

18

Em 2002, com o texto "Is Global Warming Harmful to Health?" (ver texto na página 160) e, em 2005, com o texto "Battle over Texas sex-ed textbooks" (ver texto na página 157), ambos os textos mostram as posições dos autores e questões do tipo apreensão de julgamento de valor foram desperdiçadas. 
Foi observada uma questão do tipo ordenação e relevância no vestibular de 2002, no texto "Is Global Warming Harmful to Health?". O texto se desenvolve de tal forma que podemos perceber uma ordenação e relevância de conseqüências boas e ruins do aquecimento global. Os exemplos listados vão dos mais conhecidos pelo leigo aos menos familiares. Para que o leitor/candidato respondesse à questão 3, ele deveria se ater a essa estrutura textual.

Após essa análise, podemos afirmar que há uma predominância de questões do tipo reconstituição da informação pontual linear e não linear com predominância de lineares. Como observado anteriormente, há poucas questões do tipo apreensão do julgamento de valor, ordenação e relevância, estabelecimento de relações, reconstrução do quadro enunciativo, reconstituição da argumentação. Isso mostra que os exames se restringem a um nível de leitura que exige do leitor/candidato o reconhecimento do texto: em geral, questões de baixa complexidade não avalia leitura propriamente dita (compreensão).

Pelo fato de o exame concentrar sua avaliação em torno de questões do tipo reconstituição de informação (linear, pontual e orientada), o exame de inglês do vestibular da UFPR não cumpre totalmente com sua função de avaliar a leitura como um processo mais complexo de construção de sentidos. Além disso, é um exame inconstante, pois os tipos de questões com predominância argumentativa que aparecem são poucos e o número delas oscila muito de ano para ano (veja quadro 7).

Quando um exame limita-se a questões com informativas (linear, pontual e orientada), a visão de leitura subjacente continua sendo a do modelo ascendente. Quero deixar claro que o ensino da leitura no nível de reconstituição da informação é condição necessária, mas está longe de ser suficiente para a leitura enquanto construção de sentidos, vista numa dimensão discursiva. Concentrar o exame em questões de reconstituição de informação pontual linear e orientada pode sinalizar que o exame tenha uma maior probabilidade de exercer um efeito retroativo negativo no ensino que o precede. Isso porque aspectos primordiais e desejáveis a serem abordados em aula, tais como reconstrução da cadeia argumentativa (não linear global e não orientada), apreensão de julgamento de valor, estabelecimento de relações, reconhecimento do quadro enunciativo (de modo não linear, global e não orientada), intenção do autor/texto, dentre outras, podem ser negligenciados, uma vez que tais tipos de questões não são primordialmente cobrados no exame.

Além do problema com os tipos de questões avaliados, há também um outro problema: algumas provas cobram construtos diferentes como o de 2005, 
por exemplo, que, nas questões 75 e 76, avaliou a língua (léxico) e não a leitura em si. ${ }^{7}$ Tal disparidade pode estar relacionada à maneira como o exame é elaborado. Hoje, existem dois 'estruturadores' de provas de língua inglesa, que podem elaborar toda a prova ou solicitar a outras pessoas que a elaborem também, mas eles são os responsáveis pela prova como um todo. Cada examinador elabora um conjunto de três questões que são relacionadas para formar um banco de questões. Por uma questão de sigilo, os examinadores não sabem quais textos do banco de questões e itens serão escolhidos para serem utilizados em um determinado vestibular. Portanto, o exame pode conter questões escritas por algumas pessoas que nunca se reuniram para discuti-las. Aqui, pode estar o problema da falta de uniformidade nas provas. Caso a prova não seja elaborada por uma equipe com visões de linguagem, de leitura e de avaliação convergentes e, caso esse grupo não se reúna, discuta e argumente sobre os textos, questões e respostas, o exame poderá parecer como uma colcha de retalhos.

Se a equipe de elaboradores concentrasse seus esforços para uniformizar suas concepções de língua, leitura e avaliação; se integrantes da equipe começassem a elaborar juntos outros tipos de questões além das de reconstituição da informação e que fossem (não lineares, não orientadas e globais) , tais mudanças poderiam levá-los a avaliar a leitura propriamente dita, e assim, o exame de inglês tornar-se-ia um instrumento com potencial para um efeito retroativo positivo. $\mathrm{O}$ que falta a essa equipe é um documento com as especificações do exame - qual é a natureza do exame, quais são os componentes desse exame, qual é a concepção de língua e leitura subjacente ao exame, quais são os tipos de questões cobrados e por quê - são alguns aspectos importantes a serem incluídos no manual do candidato, por exemplo. Como visto no item 4.1.4, o manual do candidato não oferece embasamento teórico e informações suficientes para que os elaboradores possam escrever provas consistentes, com validade de construto e sistêmica (potencial para efeito retroativo benéfico); e nem para que os professores do ensino médio, por exemplo, possam referendar seu planejamento satisfatoriamente.

Um outro aspecto, que deve ser abordado aqui é o método de avaliação utilizado: a múltipla-escolha simples. O exame de inglês do vestibular da UFPR acontece na primeira fase do concurso. Dentre as oitenta questões de múltipla-

7 Se, ao menos, os elaboradores tivessem perguntado qual a relação das palavras escolhidas ('because' e 'indeed') com a argumentação do texto, as questões seriam do tipo reconstrução da argumentação. Porém, o que realmente foi cobrado foi somente se o leitor/candidato sabia o significado dessas palavras. 
escolha simples do exame, oito são de língua estrangeira. Isso representa 10\% do exame na primeira fase. A língua estrangeira não é avaliada na segunda fase quando questões dissertativas são elaboradas. Questões abertas bem elaboradas cobrando os diferentes tipos, obrigariam o leitor a fazer, "sozinho", o percurso de leitura da questão, ao passo que, com múltipla-escolhas, ele somente tem que refutar as alternativas incorretas e confirmar as corretas. Isso faz com que ele apenas reconheça o caminho de leitura feito pelo próprio elaborador. O leitor/candidato jamais fará sozinho o percurso de reconstituir informações, ordenar, estabelecer relações, reconhecer o quadro enunciativo, apreender um julgamento de valor ou reconstruir uma argumentação, pois as alternativas já estão previamente dadas e, portanto, cabe a ele somente confirmá-las ou refutá-las. A construção de sentidos através da leitura em si não pertence ao leitor; o sentido já vem determinado nas alternativas e cabe ao leitor/candidato identificar o sentido criado por outro.

Por isso é que muitos leitores/candidatos experientes em múltipla-escolha lêem as alternativas antes de lerem os textos (Retorta, 1996), pois buscam os sentidos construídos nas alternativas e vão confirmá-las ou refutá-las no texto.

Portanto, a múltipla-escolha pode exercer, potencialmente, um efeito retroativo negativo se ao invés de levar o leitor/candidato à construção de sentidos dos textos, leva-o a buscar testwiseness techniques ${ }^{8}$ (estratégias oportunistas de teste, tradução minha) para responder às questões satisfatoriamente. O processo de construção de sentidos feito pelo leitor sofre interferências de tais estratégias, e no final, não se sabe se o leitor/candidato lê de fato ou somente tem técnicas (estratégias oportunistas) para responder a uma prova de múltipla-escolha.

O método de múltipla-escolha, apesar de ser considerado um dos mais confiáveis (Huges, 1989, p. 59; Weir, 1990, p. 43), também é um dos métodos menos válidos, isso porque tal método impede o examinador de avaliar o leitor/ candidato diretamente através de seu desempenho de tarefas que se assemelham àquelas encontradas em situações de leitura da vida real (Baker 1989, Huges 1989, Oller, 1979, Weir, 1990). Portanto, o resquício da era psicométri-

8 Estratégias oportunistas de teste (testwiseness techniques) são estratégias que os examinandos utilizam para lidar com os métodos de avaliação em si e não com o construto que está sendo avaliado. Por exemplo, em um teste de leitura com o método de múltipla-escolha, alguns examinandos lêem as questões e alternativas antes de ler o texto para poderem mapear no texto possíveis respostas. 
co-estruturalista ${ }^{9}$ (avaliação indireta da língua - ver item 2.1.2) fica impregnado no próprio método de avaliação, impossibilitando o examinador de avaliar os leitores/candidatos com instrumentos postulados pela era psicolingüísticosociolingüística (avaliação direta por desempenho - ver item 2.1.5).

A partir de 1995, os elaboradores das provas de inglês da UFPR tentaram adequar seus exames ao paradigma da era psicolingüístico-sociolingüística, quando abandonaram questões de itens isolados e privilegiaram questões de leitura. Concentrar a prova na leitura foi uma tentativa de avaliar a capacidade do leitor/candidato de usar a língua demonstrando seu desempenho real, a fim de analisar se ele tem competência ou não de usar a leitura em contextos que correspondam à vida real, ou seja, textos acadêmicos em língua inglesa. No entanto, apesar da tentativa, os elaboradores dos exames parecem não ter abandonado a visão ascendente de leitura, pois focaram a avaliação em questões de reconstituição de informação pontual linear e orientada. Como já dito anteriormente, avaliar primordialmente questões desse tipo não é suficiente para a leitura enquanto construção de sentidos. Como os exames ainda estão atrelados à uma visão de leitura como extração de significados, a validade deles pode estar comprometida uma vez que tais exames não são pontencialmente bons para exercer um efeito retroativo positivo (Bachman 1990, Messick 1996).

\subsubsection{Os planos de aulas dos professores de cada escola}

O plano de ação global (Anexo H.4) é o documento oficial do Colégio LC O plano, que é elaborado com as outras colegas da disciplina, segue o programa do livro texto adotado pela escola. As competências e habilidades propostas pelo documento não foram trabalhadas. O documento é um 'colcha de retalhos' de itens retirados dos PCN+ e do índice do livro do IBEP.

Como pude notar, houve uma escolha aleatória de algumas das muitas competências sugeridas no $\mathrm{PCN}+$ e que os professores julgaram mais importantes para incluir no texto, além da cópia do índice do livro didático - Essential English da editora IBEP. Não há qualquer relação lógica e coerente entre as competências escolhidas e os conteúdos propostos para serem trabalhados. É um documento mal elaborado e sem coerência (sem falar do desmazelo do documento original. Ver Anexo H.3). Dificilmente algum professor pode proporcionar um bom curso baseado nesse documento.

$9 \quad$ O método da múltipla-escolha surgiu na era psicométrico-estruturalista, período no qual se acreditava poder fragmentar a língua para ensiná-la ou avaliá-la indiretamente. 


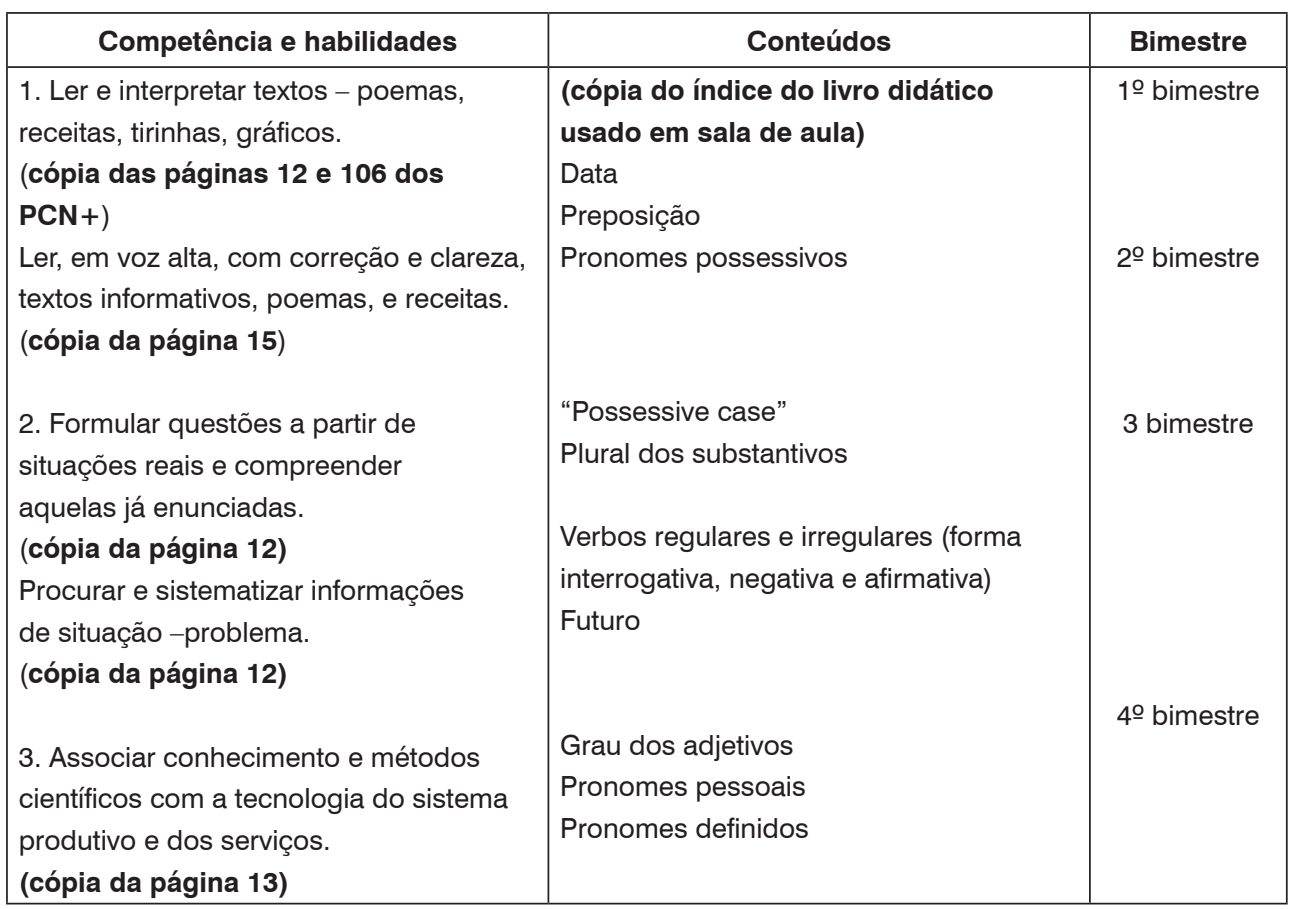

O plano de aula da Escola E. F. A (Anexo G.4) também foi baseado no índice do livro de Amadeu Marques. É um programa bem tradicional, aos moldes do Método Gramática-Tradução. Na verdade, na falta de um programa único e coeso da Secretaria Estadual da Educação, tanto o programa da Escola LC quanto o da Escola EFA são cópias dos índices dos livros-textos adotados pela escola.

Enquanto as escolas particulares seguem o programa do vestibular da UFPR, as escolas públicas elaboram seu planejamento de acordo com suas impressões dos PCN+ e o livro didático. São, em geral, documentos baseados em gramática sem qualquer conexão com as competências e habilidades sugeridas pelos documentos oficiais. Além disso, não há um programa coeso e coerente das séries do fundamental e não há uma seqüência lógica entre o ensino fundamental e o ensino médio. Um problema adicional é que as escolas podem optar por colocar ou não o inglês nas três séries do ensino médio. Portanto, há escolas cujos alunos têm a disciplina nos três anos, porém há outros que têm a disciplina somente no último ano do ensino médio e, portanto, cada escola elabora um plano de aula próprio.

A diferença entre as escolas públicas e particulares é que as particulares e cursos pré-vestibulares têm um programa com um objetivo único: trabalhar a habilidade de leitura, enquanto as públicas ainda continuam nas aulas de gramática. 


\subsection{4 manual do candidato do vestibular da UFPR}

O guia do candidato traz informação para os candidatos sobre o calendário dos exames, a inscrição, os cursos e vagas existentes, vagas de inclusão social e racial para candidatos de baixa renda e afrodescendentes, um questionário sócio-educacional.

As provas de línguas estrangeiras modernas (alemão, espanhol, francês, inglês e italiano) são embasadas no seguinte programa:

"A prova de Lingua Estrangeira Moderna tem por objetivo avaliar a capacidade do candidato de compreender textos em lingua estrangeira, que apresentem nível de complexidade lingüistica e cultural compatível com o Ensino Médio. As questões deverão verificar até que ponto o candidato:

- Identifica ideias principais e ideias específicas do texto;

- Estabelece relações entre diferentes partes do texto;

- Estabelece relações entre texto e contexto;

- Identifica diferentes pontos de vista apresentados no texto.

Os textos utilizados poderão ser jornalísticos, publicitários, de divulgação científica ou literários. O conhecimento gramatical será avaliado em nível funcional, ou seja, como elemento necessário para a compreensão dos textos."

Se compararmos a análise das provas (item 4.1.2) com o programa proposto, observamos que nem todas as questões que deveriam ser avaliadas de acordo com o manual são, de fato, avaliadas. Questões como 'estabelece relações entre diferentes partes do texto'; 'estabelece relações entre texto e contexto' e 'identifica diferentes pontos de vista apresentados no texto' são esporadicamente cobradas nas provas e, quando são, somente uma ou duas questões, no máximo, desses tipos são contempladas. As provas concentram grande parte da avaliação em 'identificação de ideias principais e ideias específicas do texto'.

Percebemos que o programa dá ênfase na interpretação de textos sem desconsiderar o conhecimento implícito da estrutura da língua. Porém, é um documento superficial e hermético demais. Informações importantes, tais como quais são as concepções de língua, leitura e avaliação que subjazem a do exame, quais são os componentes do exame, que tipos de questões são avaliadas, são desprezadas. O programa não oferece embasamento teórico e informações suficientes para que os professores possam referendar seu planejamento satisfato- 
riamente. Como o documento não explicita quais são as concepções de linguagem e leitura que estão subjacentes ao exame, nem quais abordagens seriam apropriadas para desenvolver a habilidade de leitura, fica difícil para o professor inferir tais informações. Não há exemplos nem referência bibliográfica. Já que muitas escolas, diretores e professores utilizam o programa para planejarem seus cursos, seria interessante que o documento contemplasse o máximo de informação possível em termos de concepções e filosofia que embasam o exame, além de uma bibliografia que traz essas teorias. Seria necessário também incluir questões anteriores comentadas para mostrar que tipos de questões são avaliados.

\subsection{PERCEPÇÃO DOS ELABORADORES DO EXAME}

Para o examinador A, a prova de língua inglesa do vestibular da UFPR prioriza a avaliação de compreensão de leitura em língua estrangeira. Tal prova visa a "verificar se o candidato possui habilidades que vão desde aspectos de decodificação do texto até uma compreensão da intenção do autor, fazer relação entre partes do texto, dentre outras". Para o examinador B, a prova deve avaliar a compreensão de leitura de textos de diferentes gêneros e, para o examinador C, o candidato deve demonstrar domínio de estratégias de leitura que o leve a compreender o texto, além de mostrar conhecimento de determinados aspectos gramaticais. Através das respostas da pergunta sobre a(s) filosofia(s) que embasa (m) as provas de língua inglesa, pude perceber, apesar de priorizar a avaliação de leitura, que os examinadores A e C, às vezes, postulam a avaliação da língua, uma vez que para o primeiro "aspectos de decodificação" do texto são cobrados, ao passo que para segundo "aspectos gramaticais" são levados em consideração ao elaborar a prova, e às vezes, seus discursos sinalizam para uma visão como construção do significado, como "compreensão da intenção do autor" e "fazer relação entre partes do texto". Já o examinador B falou sobre a filosofia que embasa suas provas de modo sucinto e genérico e, portanto, ficaria difícil inferir qual a sua visão de leitura. Segundo os elaboradores, nenhum documento oficial é consultado para direcionar a elaboração do exame de inglês do vestibular da UFPR.

Segundo os examinadores A e C, quanto ao grau de dificuldade, os textos são difíceis. Para o examinador B, os textos são muito difíceis e "às vezes estão muito além do conhecimento do ensino médio", sentimento esse compartilhado pelos outros examinadores. Se os três elaboradores têm consciência do grau de dificuldade dos textos, e um deles afirma que tais textos estão aquém do nível médio, cabe perguntar aqui se o exame almeja um candidato que tenha 
um conhecimento de língua que nem a escola pública nem a privada podem oferecer. Caso a universidade almeje candidatos com um conhecimento maior daquele que as escolas atualmente podem oferecer, por que os elaboradores do exame não focalizam na validade sistêmica e trabalham para que o exame exerça um efeito retroativo positivo no ensino médio?

Um aspecto que desagrada aos examinadores é o "número limitado de questões de língua estrangeira" (8 questões) e "o fator eliminatório que a prova tem ao invés de ser classificatório." Apesar disso, o que mais os examinadores gostam em relação à prova de língua inglesa é o fato de ser uma avaliação de leitura, com ênfase na compreensão, sem questões descontextualizadas sobre gramática. Como o foco da prova, segundo os examinadores, é na compreensão da língua alvo, os enunciados das questões são escritos ora em língua materna, ora na língua alvo, uma vez que enunciados em língua estrangeira podem interferir na compreensão do texto em si. Apesar de os elaboradores focarem a avaliação na leitura, o que se nota, na prática, é que nem sempre o foco é exclusivo nessa habilidade. Em alguns exames, algumas questões giram em torno de estruturas lingüísticas.

Quanto ao Guia do Candidato, o examinador A tem consciência de que o programa é superficial e não dá conta de questões primordiais, tais como concepções de linguagem, de leitura e de avaliação. Ele afirma que:

infelizmente, isso não é suficiente para a maioria dos candidatos. Os professores de ensino médio necessitam de informações detalhadas para preparar adequadamente seus alunos. Seriam indispensáveis encontros dos examinadores com os professores do ensino médio, e fornecimento de material a eles, para esclarecer o que realmente se deseja com a prova.

Para os examinadores B e C, o guia orienta bem os candidatos. Os dois examinadores não se ativeram que o documento é falho e insuficiente para servir como parâmetro para elaboração de qualquer planejamento de ensino. Mas, como eles não acreditam que o exame de inglês do vestibular possa tornar-se um instrumento balizador no ensino médio, não há uma preocupação de tornar o manual do candidato um documento que atinja os professores e alunos do ensino médio.

Em relação ao efeito retroativo da prova de língua inglesa do vestibular da UFPR, os examinadores afirmam que o exame, a priori, não deveria ser um mecanismo de mudanças no ensino de língua estrangeira no ensino médio. 
Ao falar sobre o assunto, o examinador A afirma:

O exame não pode ter como objetivo acarretar mudanças no ensino médio. O ensino médio está atrelado demais ao vestibular. Não se pode comentar sobre esse fato como lamento, e ao mesmo tempo tentar influenciar - através do vestibular - o ensino médio.

Por outro lado, independente de nossa intenção, o exame tem algum efeito sobre o ensino nos anos anteriores. Mas esse efeito é muito mais no sentido de copiar externamente o formato do material que se dá aos alunos.

Um efeito positivo tem sido a minimização do estudo descontextualizado da gramática.

De forma geral, minha opinião é que o exame não deve ser utilizado como mecanismo de mudanças no ensino de língua estrangeira no ensino médio.

Portanto, o examinador A não acha que um exame pode, e nem deve, ser um eficiente mecanismo de mudanças no ensino/aprendizagem que o precede, mesmo que o exame seja bem elaborado e tenha um bom potencial para tal. Ele tem consciência de que o exame influencia o ensino que o precede, independentemente de sua vontade, e sabe que o impacto, muitas vezes, se restringe ao formato do exame e não no conteúdo e metodologia de ensino em si. Porém, ele nada faz para reverter os equívocos que a falta de informação sobre o exame pode causar (ou causa).

O examinador B também não acredita que o exame possa ser um bom mecanismo para estimular mudanças e afirma que o exame provoca alterações no ensino de língua estrangeira no ensino médio, mas que tal fenômeno não deveria ter tanta força. Ele assevera que:

Embora ache que o ensino médio não deveria ter como objetivo primeiro a aprovação dos alunos no vestibular, percebo que é isso o que infelizmente acontece. Assim, o tipo de questões dos vestibulares acaba direcionando o que é ensinado no ensino médio. Acho que o ensino médio está voltado para a aprovação dos alunos no vestibular e, portanto, direciona suas estratégias para isso. Entretanto, outros fins educacionais mais do que mercadológicos - deveriam nortear o ensino médio, de vez que o vestibular me parece apenas uma medida contingente que deveria ser provisória - a universidade deveria oferecer vagas para todos os alunos egressos do ensino médio... 
Para ele, o exame do vestibular alimenta uma indústria de cursos prévestibulares e materiais didáticos, o que constitui uma influência negativa, mas não acredita que a prova possa influenciar positivamente o ensino e aprendizagem no ensino médio.

Portanto, tanto o examinador A quanto o B não acreditam que seu exame de vestibular possa ser um instrumento balizador do ensino da língua inglesa no ensino médio. Essa crença pode estar atrelada ao fato de eles não conhecerem o fenômeno do efeito retroativo e seu poder potencial para direcionar o ensino que o precede.

O examinador C, por sua vez, percebe uma influência positiva do efeito retroativo, quando afirma que: "no ensino médio o trabalho é feito para o vestibular. Assim sendo, informações contextualizadas são trabalhadas cada vez mais."

Porém, há uma influência negativa quando ele afirma existir uma preocupação excessiva somente com o exame vestibular, e muitas vezes negligenciando-se uma ligação adequada entre o que ensinar no ensino médio com o que foi ensinado no ensino fundamental. Ele ressalta que: "entretanto, há um enorme gap entre o ensino fundamental e médio porque, ao invés de se dar continuidade ao que vinha sendo ensinado, passar no vestibular passa a ser o único objetivo". Novamente, apesar de ele afirmar que o exame já mudou significativamente o ensino da língua inglesa no ensino médio, ele desconhece o poder potencial do exame em mudar não apenas o enfoque de ensino - no caso a primazia da leitura - mas também os conteúdos a serem ensinados e a forma de ensinar.

Os examinadores compartilham da convicção de que seus exames de língua inglesa do vestibular causam não só mudanças positivas no ensino médio em termos do ensino de gramática - a visão estruturalista da língua passa a dar lugar para uma visão contextualizada da gramática -, como mudanças negativas, quando se enfatiza o treinamento do formato da prova: múltiplaescolha somatória até 2004 e, atualmente, múltipla-escolha simples.

Porém, como ressalva o examinador A, outro ponto negativo da prova de inglês do exame vestibular é que os professores do ensino médio, muitas vezes, não conseguem ter uma visão clara de que tipo de compreensão de texto o exame cobra de seus candidatos. Há uma preocupação concentrada no formato da prova e uma negligência no ensino de compreensão de texto em nível macro, isto é, estabelecer relações de sentido dos textos, fazer inferências, elaborar hipóteses. Freqüentemente, o ensino de leitura se restringe à mera decodificação do texto. Nesse aspecto, o efeito retroativo do exame não consegue provocar mudanças na metodologia do ensino e limita sua abrangência à forma da prova. Essa percepção vem ao encontro das hipóteses de Alderson e 
Wall (1992) de que o exame influenciará o que é ensinado, mas não influenciará como é ensinado, como já foi constatado em outras pesquisas: Alderson e Wall (1990 e 1991); Wall (1996 e 2000); Cheng (1998); Scaramucci (1998 a, b, e c, 1999 c. 2002 a e b); Gimenez (1988, 1997, 1998, 1999). Ele afirmou que aspectos de decodificação do texto também são cobrados no vestibular da UFPR e isso poderia ser um dos fatores que leva os professores a concentrarem suas aulas em aspectos mais estruturalistas.

Percebi que dois dos examinadores, A e C, têm uma visão de língua e de avaliação de língua mais próximos do que o examinador B. Talvez essas diferenças de percepção de língua e avaliação façam com que algumas questões das provas sejam mais focadas em língua, ao passo que outras estejam mais próximas da compreensão de texto em nível macro. Interessante ressaltar é que, provavelmente, os exames não sejam feitos pelos mesmos elaboradores a cada ano, pois se observa uma diferença bastante grande nos exames em termos do que é avaliado e o grau de complexidade de textos e questões.

Um exame de alta relevância como o vestibular da UFPR poderia e deveria servir como instrumento potencial de mudanças no ensino médio. Porém, para que o exame pudesse exercer efeito retroativo positivo no ensino médio, seria necessário que: primeiro, os elaboradores compartilhassem das mesmas concepções de linguagem, de língua e de avaliação; segundo, que eles elaborassem juntos o exame e, assim pudessem discutir e padronizar os tipos de textos e questões; e, que conhecessem o fenômeno efeito retroativo a fundo e sua potencialidade em direcionar o ensino que o precede. A responsabilidade social dos elaboradores é muito grande e o efeito retroativo de seu exame não pode ser relegado.

\subsection{PERCEPÇÕES DA COORDENADORA DE LÍNGUA INGLESA DA SECRETARIA ESTADUAL DE EDUCAÇÃO}

A entrevista com a coordenadora da Secretaria de Educação teve como objetivo averiguar quais são os objetivos de ensino de língua inglesa estabelecidos pela Secretaria da Educação, conhecer o que pensa a coordenação sobre a prova de língua inglesa do exame de vestibular da UFPR e ainda averiguar se essa Secretaria reconhece a importância do efeito retroativo de um exame de alta relevância, como o vestibular da UFPR.

\subsubsection{O vestibular e a escola pública}

A coordenadora técnico-pedagógica da Secretaria Estadual de Educação é responsável pelo ensino de língua inglesa no ensino fundamental no Estado 
do Paraná, e estava interinamente responsável pelo ensino médio. Sua função é supervisionar como o ensino da língua inglesa está sendo desenvolvido nas escolas apesar de cada escola ter autonomia para criar seu próprio Projeto Político Pedagógico (PPP), ou seja, professores, orientadores, supervisores, coordenadores e diretores estabelecem diretrizes para suas escolas.

A coordenadora está na função de técnico-pedagoga há um ano, mas está na carreira de magistério há dez anos - dois anos nas escolas públicas de São Paulo, oito nas escolas públicas em Curitiba e um ano, concomitantemente com o magistério público, em uma escola particular de Curitiba. Com base em sua experiência nas duas esferas de ensino - pública e particular- a coordenadora pode, portanto, traçar o perfil sócio-econômico dos alunos das escolas públicas do Paraná e da escola particular na qual ela trabalha. As escolas públicas das quais ela é encarregada do ensino de língua inglesa recebe alunos principalmente das classes C, D e E, os da escola particular das classes A, B e C.

Segundo a profissional, a Secretaria da Educação tem por objetivo formar alunos que sejam capazes de conseguir comunicar-se em pequenas situações de comunicação e prepará-los para o mercado de trabalho, caso ele necessite da língua para desempenhar uma função. O inglês é visto como um meio para que se consiga formar um cidadão. "Ele é um mecanismo para se trabalhar outros valores, inclusive a cultura, para que esse aluno tenha uma formação crítica de cidadania."

Porém, segundo a coordenadora, muitos professores questionam se é para isso que eles querem que o aluno seja preparado: somente para o mercado de trabalho e para situações de comunicação. Questionam-se quais são essas situações de comunicação e se o aluno vai realmente passar por elas no futuro, ou seja, será que os alunos vão, em algum momento de suas vidas, precisar utilizar a língua inglesa, já que a maioria vai exercer funções (geralmente de baixa capacitação e salário) nas quais a língua estrangeira não é necessária? Outra dúvida desses professores é se o aluno vai de fato fazer vestibular tanto em instituição pública, quanto privada, e se há a necessidade real de prepará-lo para tal.

Essa visão determinista de que o inglês não é um conhecimento necessário para as classes desprivilegiadas, pois 'jamais irão utilizá-la na vida futura' é, no mínimo, perigosa. Tal discurso ideológico reproduz uma relação de dominação e cria uma "falsa consciência" sobre a realidade que visa a reforçar e perpetuar essa divisão entre trabalho intelectual e manual, ou seja, as classes A e B são eternas detentoras do conhecimento e poder, ao passo que as C, D e E são relegadas ao trabalho manual e a se sujeitarem ao domínio dessas classes dominantes. 
A coordenadora afirma que há consenso entre os professores de que seus alunos nem têm intenção de prestar vestibular em instituições públicas, pois já sabem de antemão que não têm o conhecimento necessário para disputar uma vaga em grau de igualdade com um aluno da escola particular. Esses profissionais, então, questionam se é necessário trabalhar conteúdos e matérias que surgirão no vestibular, uma vez que seus alunos nem almejam fazer terceiro grau por não serem capazes. Além disso, se os professores continuarem a pensar que o vestibular não é uma meta atingível para seus alunos e não fizerem nada para mudar esse panorama, o fracasso da escola pública ao preparar seus alunos para o vestibular é fadado a se perpetuar. Como não há orientação coerente, nem nos documentos oficiais - PCNEM, PCN+ etc. - nem da Secretaria, os professores permanecem sem objetivos claros e coesos: ensinar o quê, para quem e para quê? A coordenadora afirma que ela e seus professores se questionam sobre o fato:

Eu acho que eles [os alunos] sentem isso porque a gente divide isso com os colegas [de que seus alunos não têm condições de disputar vagas em universidades públicas com alunos de escolas particulares]. Então eu tenho a impressão que em poucas escolas estaduais do Paraná os alunos se sentem capazes, se sentem bem e falam: 'eu vou fazer vestibular'. Eu vejo isso também numa outra escola que trabalho e na qual a minha filha estuda. Ela diz: mãe, a maioria... ou sonha com a medicina, que a gente vê é praticamente somente um sonho, porque todo mundo, porque a colega falou, porque meu pai sonha. Ou ela já fala assim: eu não vou fazer nada porque não há expectativa do que vou fazer no futuro, não é o assunto, não é o que você vai fazer no vestibular. A impressão que a gente tem é que o aluno...não a gente como professor, nem a secretaria, mas o aluno não tem essa expectativa. A gente até questiona: o vestibular poderia se adaptar a essa realidade la realidade da baixa qualidade de ensino da língua inglesa nas escolas públicas e a falta de competência dos alunos para serem aprovados no vestibular]? Ou a gente teria que criar um mecanismo para que essa grande maioria tivesse acesso a isso [ao conhecimento necessário para passar no vestibular]...não sei como.

A coordenadora sabe que tem algo de errado com a escola pública, sabe identificar o que é, mas nada faz para mudar esse panorama. Se a Secretaria da Educação tivesse real interesse em melhorar a qualidade de ensino de língua inglesa no Estado, haveria vários mecanismos para isso, e o efeito retroativo do exame do vestibular seria um deles. Basta vontade política. 
Ao ser indagada sobre o papel do vestibular da UFPR na vida dos alunos e professores, a coordenadora relatou que sua experiência de escola pública e particular despertou um sentimento incômodo quando ela percebeu as diferenças gritantes entre as duas e como tais diferenças geravam um abismo. Segundo ela, esse poço ajuda a propagar a desigualdade de oportunidade de acesso às universidades públicas. Ela ilustra esse incômodo com uma experiência que teve nas escolas públicas e particulares:

Eu trabalhava, na mesma região, em uma escola particular, num terceirão, e o objetivo daquela turma era o vestibular e era a Federal. Eles faziam sempre os simulados. Todas as provas eram simulados. As apostilas voltadas para material de vestibular, só que poucos tinham real interesse em aprender. A maioria tinha uma atitude muito negativa em sala de aula. Uns 500 metros, a outra escola na qual eu trabalhava há sete anos, pública, terceiro ano, só que noturno. Os alunos do estadual, me chamavam a atenção: a vontade deles de poder ter essas informações, esse material dos demais [informações e materiais que os alunos da escola particular tinham]. Eles se sentiam diminuídos, 'a gente não tem', 'a gente não pode fazer vestibular, porque a gente não tem nível', 'a gente 'tá muito atrasado', 'a gente não vai conseguir', quer dizer 'eu vou fazer espanhol, professora, porque o inglês eu não tenho', 'eu não tive da mesma forma', 'o espanhol... eu acho que é mais fácil. Então isso é uma coisa que me chamava muito a atenção porque pensava: o vestibular me parece que acaba sendo pra poucos, né? Quer dizer...não sei se o problema é o vestibular ou se o problema é o que a gente está fazendo, ou se o problema é o sistema, não sei....

A inquietação da professora sinaliza que é consciente da degradação da educação pública no país. O problema não está no vestibular, ou seja, na avaliação em si. Como afirma Vera Zacharias na epígrafe deste capítulo, "compreender as manifestações práticas da prática avaliativa é ao mesmo tempo compreender aquilo que nela está oculto". O exame de inglês do vestibular serve como um instrumento diagnóstico e nos aponta que alunos da escola pública não têm o conhecimento desejável da língua. E é esse diagnóstico que incomoda. Talvez seja por isso que muitos professores da escola pública se defendem do fracasso escolar de seus alunos dizendo que 'não preparam para o vestibular', mas 'para vida'. Uma avaliação, como o exame do vestibular, deveria funcionar como um mecanismo que propiciasse oportunidades de ação-reflexão num acompanha- 
mento permanente da universidade e escolas de ensino médio, incitando-os a novas tomadas de decisões para a melhoria da qualidade de ensino.

Dois aspectos dessa fala chamam a atenção: a ênfase dada pela escola particular ao preparo de seus alunos para o vestibular da UFPR, fazendo uso de material dirigido para esse fim e oferecendo somente provas de simulados, ao passo que a escola pública nem sequer cogitou preparar seus alunos para o exame; e a atitude negativa que muitos alunos da escola particular tinham em relação ao curso e ao professor, de um lado, e a sensação de fracasso, impotência e exclusão que os alunos da escola pública tinham para enfrentar o vestibular. Um terceiro aspecto também merece comentário: é seu questionamento sobre de quem é a culpa do fracasso dos alunos da escola pública - 'o problema seria do vestibular, do que a gente está fazendo ou se o problema é o sistema?'. $\mathrm{Na}$ verdade, inconscientemente, ela parece saber que tal fracasso não é um problema simples e que, na verdade, envolve a negligência dos três: os elaboradores do vestibular não se comunicam com as escolas, os professores são despreparados para sua profissão e a Secretaria deixa a escola pública à deriva, sem objetivos específicos, claros e coerentes.

A sensação de fracasso e impotência dos alunos de escolas públicas diante do acesso ao vestibular de instituições públicas é também percebida pelo comentário da coordenadora quando ela dá sua opinião sobre a prova de inglês do vestibular. Para ela, "a prova de inglês do vestibular da UFPR é uma boa prova e se um aluno tiver o conhecimento necessário para ser bem sucedido no vestibular isso seria ótimo". Porém, ao falar sobre o conhecimento da língua nas escolas públicas, ela afirma que seria "ótimo se isso funcionasse na escola pública, mas os alunos não conseguem ter acesso a esses conhecimentos básicos que eles necessitam para o vestibular". Ela afirma também que o exame é bom, "mas não para nossa comunidade de escolas públicas, nossa clientela". Ela tem consciência de que se um aluno vai bem nesse exame, ele provavelmente tem um bom conhecimento da língua, porém sabe também que os alunos da escola pública nem mesmo possuem um conhecimento satisfatório da língua portuguesa.

A coordenadora sabe apontar quais são os problemas estruturais da Secretaria e do planejamento da disciplina. Para ela, a fragilidade do sistema de ensino da escola pública começa no planejamento do curso de língua inglesa. Oficialmente, os objetivos do curso são estabelecidos através do Projeto Político Pedagógico, embasados nos PCNs, desenvolvidos pelos supervisores, professores e diretores das escolas. Porém, o que se mostrou na prática foi que 
"algumas escolas tiveram discussões bastantes abertas e outras foram de gabinete, ${ }^{10}$ como a gente sabe".

Ela afirma que a falta de uma estruturação padrão e eficaz para o planejamento do curso em algumas escolas públicas abriu caminho para um autoritarismo na hora de desenvolver o PPP. ${ }^{11}$ Muitos professores receberam o documento pronto da supervisão, não lhe restando nada a fazer a não ser entrar em sala de aula com um livro-texto.

O PPP é desenvolvido pela equipe pedagógica que seria a supervisão escolar juntamente com o colegiado que seriam os professores, direção também acompanha. Me lembro da supervisão ter feito isso com a gente por áreas... onde a gente teve que pesquisar... mas a gente acabou se embasando em PCN's .... nós lemos parte dos PCN's... não foi um estudo. A gente lia alguns fragmentos ... você lê essa parte, a gente lê aquela e a gente monta alguma coisa. Foi montada a nossa parte. Há outras escolas que leram e estudaram os PCN's antes de trabalharem os PPPs. Mas eu acho que são casos isolados. A grande maioria... foi formado em gabinete. A supervisão encomenda e você escreve esse PPP. Às vezes nem passa pela mão do professor. Eu trabalhei em uma escola na qual eu nunca tive nem a oportunidade de ver o PPP da escola. Depois que foi passado, eles disseram: olha .... isso ficou assim. Ou na hora dos conteúdos. Porque ai entra a parte de metodologia e a avaliação e quais são os objetivos .... são os supervisores que fazem. Quando chegam na parte dos conteúdos: 'o que vocês acham desse, tem mais ou menos alguma coisa que eu trouxe do outro colégio?? Ai você fica tirando: acho que isso aqui não. Os conteúdos voltados para itens gramaticais. Por isso os professores já têm esses itens gramaticais nas escolas porque já vem de uma tradição.

Percebe-se, através da fala da coordenadora, que os PCNs não são inteiramente conhecidos pelos professores -"a gente lia alguns fragmentos"- apesar da tentativa de algumas poucas escolas em propiciar aos professores um estudo mais sólido sobre os parâmetros - 'há outras escolas que leram e estudaram os PCN's antes de trabalharem os PPPs. Mas eu acho que são casos isolados".

10 Decisões de gabinete são aquelas tomadas por diretores e orientadores sem a participação dos professores.

11 Os PPP (Projeto Político Pedagógico) não foram disponibilizados para a pesquisa. 
A falta de um estudo e análise cuidadosa dos PCNs impede os profissionais de desenvolverem embasamento teórico para elaborar um planejamento bem estruturado - análise essa que pode ser de criticar os documentos oficiais e propor outros modelos teóricos. A Secretaria nada faz para ajudar seus professores em seus planejamentos e consente na desorganização. Os professores não são orientados e instruídos para elaborarem seus próprios planejamentos, uma vez que os supervisores ou coordenadores de algumas escolas impõem um planejamento pronto sem permitir questionamentos - "a grande maioria [dos planejamentos]... foi formada em gabinete." Scaramucci (2001/2002, p. 99) em sua pesquisa sobre o efeito retroativo do exame de inglês da Unicamp também constatou que 'o planejamento não é elaborado para ser utilizado na orientação do ensino/avaliação mas apenas para uso burocrático, administrativo e, como tal, para permanecer "na gaveta".

Quanto aos objetivos do curso de inglês nas escolas públicas, estes são consagrados pelos livros-textos ou fragmentos deles usados em sala de aula. Como afirma a coordenadora:

Na prática, a gente sabe que muitos professores seguem o livro escolar ... o livro-texto. O livro-texto como base.... até por uma questão..) Língua inglesa não... às vezes não recebe um livro.... mas de outras disciplinas... eles recebem e para aproveitar aquele material... acaba se encaixando aquele próprio material na ementa. Ele [o professor de inglês] vai usar um livro ou ele acaba xerocando exercícios do livro-texto $e$ usa. Enfim, a gente sabe que o livro acaba... isso foi fato quando notamos na pilotagem de livros então o livro acaba direcionando as aulas.

Scaramucci (2000/2001, p. 99) também mostra em sua pesquisa que os PCNs não auxiliam os professores a elaborarem objetivos específicos de ensino e avaliação, e, por esse fato, os planejamentos de curso também não são desenvolvidos em sintonia com documentos oficiais. Ela afirma que:

Os Parâmetros Curriculares Nacionais ou PCNs são uma proposta curricular, e, como tal, sugerem objetivos gerais para o ensino. A explicitação de objetivos específicos, aqueles que são utilizados na definição dos conteúdos e operacionalizados em sala de aula são tarefas do professor que, levando em conta a situação específica, o nível dos alunos, as características da escola, enfim, uma análise das necessidades de sua clientela, determina quais aspectos de um currículo geral são mais adequados e devem ser priorizados. 
A falta de entendimento que os professores têm dos PCNs, assim como do que é efeito retroativo positivo, leva-os a estipularem objetivos específicos, muitas vezes, a partir dos índices dos livros didáticos adotados pela escola. Assim, o único instrumento que pode oferecer um norte para esses profissionais acaba sendo somente os livros didáticos. Scaramucci (op. cit., p. 99) mostra como tal falta de entendimento pode desestabilizar o ensino e avaliação em sala de aula:

Essa desarmonia [desencontro entre objetivos de ensino e de avaliação, assim como a falta de coerência entre a abordagem de ensinar e a de avaliar] é causada, sobretudo, pela não explicitação de objetivos específicos por parte do professor. Seu planejamento não é elaborado para ser utilizado na orientação do ensino/avaliação mas apensas para uso burocrático, administrativo e, como tal, para permanecer "na gaveta". Quem assume esse controle é o material didático escolhido pelo professor ou determinado pela escola, que tem seus próprios objetivos e, subjacente, também uma abordagem, a de seu autor.

Além do autoritarismo de muitas escolas na hora do planejamento da disciplina e da falta de entendimento por parte dos professores do que são os PCNs e as teorias de ensino/aprendizagem de línguas estrangeiras, a coordenadora também reclamou da falta de continuidade e consistência das determinações sobre o ensino que são repassadas pelas autoridades superiores.

O professor demora uns dez anos para se adequar a alguma coisa nova. A gente 'tá pensando em PCN's e trabalhar por projetos e trabalhar por tema. Quando você começa a entender isso, veio uma outra abordagem e diz: não. Já não é mais tão bom isso agora, vamos mudar.. é complicado, né?

Logo, fica inviável um aluno que estuda a maior parte de sua vida em uma escola pública conseguir ser aprovado em um concurso de vestibular de uma instituição pública, e, quando isso ocorre, ele geralmente tem dificuldade em terminar o curso por falta de conhecimentos necessários.

Quando a coordenadora foi questionada a respeito do fato de as escolas públicas não prepararem seus alunos para terem acesso aos vestibulares, ela afirmou que não era somente uma questão financeira, mas um problema de base. Ela assevera que uma criança de escola particular, desde pequena, recebe um ensino diferenciado, e, ao chegar ao ensino médio, já acumulou conhecimento suficiente para acompanhar as exigências do vestibular. 
[O problema da escola pública] não é uma questão somente financeira. Já vem da base. Se não houver uma boa base... a criança da escola particular tem inglês desde a primeira série, pra não dizer do jardim. Eles já vêm numa linha crescente, quando eles chegam na $5^{a}$ série o conhecimento dele já é melhor do que aquele que outro do estadual que está começando o inglês na $5^{a}$ série. Além do apoio dos pais que estão sempre incentivando o estudo. Outro fator são os cursos feitos fora da escola. Nas escolas particulares, muitas crianças fazem cursos em escolas particulares. Então aquele conhecimento ele já domina quando ele chega no segundo grau, aquele conteúdo já havia sido estudado há muito tempo. Então era repetitivo e chato. Já no colégio estadual aquilo é novo pra ele. Ele talvez não tenha aquela motivação de saber que vai fazer o vestibular então de repente você tem meia dúzia que está interessada, mas a grande maioria não quer nem saber. Então você não consegue avançar muito porque você tem que acompanhar a grande maioria. Então esses são os fatores que mais contribuem para tal diferença.

O professor, muitas vezes, se vê na obrigação de baixar o nível de suas aulas para criar condições mínimas para a maioria dos alunos serem aprovados. Caso ele insista em atender os poucos alunos interessados em aprender para o vestibular, corre-se o risco de haver uma reprovação em massa, ou seja, uma prática totalmente desaconselhável nas escolas públicas.

Portanto, notamos que o problema começa no ensino fundamental e vai aumentando até chegar ao final do ensino médio. A detonação do problema ocorre quando, ao final do ensino médio, os alunos percebem que não têm conhecimento para ingressar no ensino superior, nem capacidade para um trabalho qualificado e melhor remunerado. A educação pública neste país parece não estar preparada para educar seus cidadãos de fato.

\subsubsection{O vestibular da UFPR}

Para a coordenadora técnico-pedagógica da Secretaria Estadual de Educação, a prova de língua inglesa do exame de vestibular da UFPR é muito difícil para o aluno de escola pública. Ela afirma que o candidato que se sai bem nessa prova provavelmente manuseará bem textos na língua inglesa, caso o seu futuro curso universitário exija. Porém, aquele que passou no vestibular com um escore mais baixo, talvez não tenha a mesma facilidade. Ela também acha interessante o exame não cobrar mais itens isolados de gramática. A prova 
para ela "é elaborada de uma forma que o candidato tem que demonstrar que ele tem o conhecimento de itens gramaticais para que ele possa entender o texto. O professor ensina a gramática, ele ensina a interpretação e aí vem a prova e tudo fica perfeito. Tudo funciona."

Porém, ao falar das aulas de língua inglesa na escola pública, ela diz que muitas delas ainda trabalham a gramática isoladamente, ao passo que as particulares já se adaptaram à tendência do ensino de leitura de textos.

Aquelas escolas, que têm o material e que têm condições de poder estar acompanhando tudo isso, mudaram e talvez elas tenham sucesso... que são as escolas particulares, mas as escolas estaduais ainda não tiveram esse espaço ou talvez a possibilidade ou o professor não... por falta de suas próprias leituras, capacitações, ou seja lá de que forma for, ainda trabalha.... ah... até por uma questão de abordagem de livro didático... a gramática. Se você for olhar os livros didáticos de ensino médio, eles trabalham com uma abordagem, muitos deles, gramatical. Então ele prepara o aluno com esse conhecimento, e na prova ele vai encontrar um outro conhecimento.

Portanto, é o livro didático - estruturalista - que está dando o norte ao ensino de língua inglesa na escola pública, e não o exame vestibular, ou PCNs, ou orientações da Secretaria. O aluno da escola pública que deseja prestar vestibular lida basicamente com duas dificuldades: primeiramente, poucas turmas têm um livro-texto para trabalhar em sala de aula e quando um professor consegue usar um livro, geralmente é de baixa qualidade. Quando, esporadicamente, o professor leva um livro de boa qualidade, ele tira cópias de exercícios para seus alunos, e esses alunos, muitas vezes, não têm o conhecimento adequado para poder acompanhar as atividades propostas nos exercícios de livros mais modernos.

Eu acho que eles pensam, eles gostariam [de ter livros direcionados para o vestibular], mas o acesso ao livro é complicado. Primeiro que os alunos não têm livros de inglês, não têm. Então o professor procura obter um livro bom para que ele possa trabalhar. Só que de repente aquele material é muito bom, só que ele teria que ter tido vários pré-requisitos pra poder chegar naquele ponto, ai você acaba voltando pra os itens, novamente, gramaticais, as estruturas da língua porque são mais fáceis de você trabalhar... pra que depois...imaginando que o aluno possa fazer toda união esses conteúdos e se sair bem naquele ponto. 
Será que essa inabilidade de lidar com livros didáticos de melhor qualidade é fruto do despreparo teórico e de língua dos professores? Será que se houvesse um planejamento coerente desde a $5^{\text {a }}$ série até o $3^{\circ}$ ano do ensino médio, e professores capacitados, os alunos não teriam condições de acompanhar livros didáticos de qualidade?

Ao ser questionada se o exame de vestibular poderia ser um mecanismo eficiente de mudanças no ensino de inglês nas escolas de ensino médio, a coordenadora disse que um exame não deveria balizar o ensino que o precede pelo fato de exames suscitarem a competição, e isso não seria um objetivo adequado para quem quer formar um cidadão. Tal afirmação contradiz o que ela havia dito anteriormente sobre a supremacia das escolas particulares, em detrimento das públicas, em preparar seus alunos para o vestibular. Ela afirma que a Secretaria tem uma preocupação em oferecer uma boa formação integral aos seus alunos como nos colégios particulares. Porém, a meta 'formar o cidadão para o trabalho' também é questionada, mesmo porque para que um cidadão tenha um emprego com um salário razoável no mercado formal, ele precisa, geralmente, passar pela universidade. Segundo a coordenadora, a Secretaria da Educação também teve uma preocupação grande, nos últimos três anos, em capacitar os professores de língua inglesa e ofereceu, juntamente com o Núcleo de Assessoria Pedagógica da UFPR, diversos cursos, tanto de capacitação profissional, quanto de língua para melhorar a proficiência dos professores. Ela afirmou que a Secretaria e os professores buscam outros caminhos para o ensino de língua inglesa no Paraná. Através dos seminários - Rumos para língua inglesa no Paraná ${ }^{12}$-, esses profissionais vêm traçando outros objetivos para seu ensino, tentando transformar a língua em um mecanismo de ensino de cultura, cidadania e valores que podem também propiciar aos alunos condições para que eles possam ter acesso ao vestibular, e não somente prepará-los para esse fim como as escolas particulares fazem. É possível notar que com esse discurso, ela volta a ser a 'autoridade' e abandona toda a trajetória de ensino que havia relatado.

Os PCNEM e PCN+, apesar de afirmarem que a leitura em língua inglesa deva ser priorizada no ensino médio, não contemplam diretrizes eficientes para que os professores possam elaborar um planejamento de aula adequado para o

12 Evento no qual dois ou mais expositores apresentam vários aspectos de um determinado assunto. É uma seqüência concentrada de atividades com o fim específico de desenvolver capacidades, conhecimentos e aprendizagem por meio do trabalho. A ideia é somar informações e experiências. 
ensino de leitura. Tais documentos não são utilizados pelos elaboradores do exame de inglês do vestibular da UFPR para direcionar a preparação das provas. E, apesar dos elaboradores terem abandonado a avaliação de itens isolados de língua, uma visão tradicional de língua e de leitura é percebida nos exames. Isso pode levar os professores a continuarem a ensinar leitura nos moldes tradicionais, com gramática descontextualizada e tradução: um efeito retroativo não desejável.

Apesar de os elaboradores do exame de inglês do vestibular da UFPR serem conscientes de que o exame exerce influência no ensino médio, afirmam serem contra o vestibular servir como um instrumento balizador do ensino médio. Essa posição talvez seja decorrente do desconhecimento do potencial norteador que um exame de alta relevância bem elaborado pode exercer no ensino que o precede.

A coordenadora para língua inglesa da Secretaria Estadual da Educação do Paraná, por sua vez, assevera que os PCNEM, PCN+ e DCNEM são usados com restrições pelo fato de os professores não os conhecerem e não os entenderem. A coordenadora desconhece o imenso potencial benéfico que um exame de vestibular pode exercer no ensino médio e, já que as escolas públicas definiram que não prepararão seus alunos para o ensino superior, o programa do exame de inglês do vestibular da UFPR não é conhecido e nem utilizado para balizar o ensino médio das escolas públicas.

Neste capítulo, pudemos chegar à conclusão de que o exame de inglês do vestibular da UFPR continua inserido predominantemente em uma visão de leitura ascendente, e por esse motivo, não é um bom instrumento potencial para exercer um efeito retroativo positivo no ensino que o precede. Também pudemos observar que o efeito retroativo parece ser um fenômeno pouco relevante para o(s) autor(es) dos PCNs, elaboradores do exame de inglês do vestibular e coordenadora da Secretaria Estadual da Educação do Paraná, uma vez que não pude ver nos documentos e nas falas desses participantes indícios de que o efeito seja uma preocupação consciente.

\section{NOTA}

i Positive Washback should be a primary goal for test developers. 